\title{
Arsenic and high affinity phosphate uptake gene distribution in shallow submarine hydrothermal sediments
}

\author{
Ernest Chi Fru • Nolwenn Callac $\cdot$ Nicole R. Posth $\cdot$ Ariadne Argyraki \\ Yu-Chen Ling • Magnus Ivarsson • Curt Broman · Stephanos P. Kilias
}

Received: 1 May 2018/ Accepted: 14 September 2018/Published online: 20 September 2018

(C) The Author(s) 2018

\begin{abstract}
The toxicity of arsenic (As) towards life on Earth is apparent in the dense distribution of genes associated with As detoxification across the tree of life. The ability to defend against As is particularly vital for survival in As-rich shallow submarine hydrothermal ecosystems along the Hellenic Volcanic Arc (HVA), where life is exposed to hydrothermal fluids containing up to 3000 times more As than present in seawater. We propose that the removal of dissolved As and phosphorus (P) by sulfide and
\end{abstract}

Responsible Editor: Maren Voss.

Electronic supplementary material The online version of this article (https://doi.org/10.1007/s10533-018-0500-8) contains supplementary material, which is available to authorized users.

\section{E. C. Fru · N. Callac $\cdot$ C. Broman}

Department of Geological Sciences and Bolin Center for Climate Research, Stockholm University,

10691 Stockholm, Sweden

E. C. Fru $(\bowtie)$ · Y.-C. Ling

College of Physical Sciences and Engineering, School of Earth and Ocean Sciences, Geobiology Center, Cardiff University, Park Place, Cardiff, Wales CF10 3AT, UK e-mail: ChiFruE@cardiff.ac.uk

N. R. Posth

Department of Biology, Nordic Center for Earth Evolution (NordCEE), Campusvej 55, 5230 Odense M, Denmark
$\mathrm{Fe}(\mathrm{III})$ (oxyhydr)oxide minerals during sediment-seawater interaction, produces nutrient-deficient porewaters containing $<2.0 \mathrm{ppb} \mathrm{P}$. The porewater arsenite$\mathrm{As}(\mathrm{III})$ to arsenate-As(V) ratios, combined with sulfide concentration in the sediment and/or porewater, suggest a hydrothermally-induced seafloor redox gradient. This gradient overlaps with changing high affinity phosphate uptake gene abundance. High affinity phosphate uptake and As cycling genes are depleted in the sulfide-rich settings, relative to the more oxidizing habitats where mainly $\mathrm{Fe}(\mathrm{III})$ (oxyhydr)oxides are precipitated. In addition, a habitatwide low As-respiring and As-oxidizing gene content relative to As resistance gene richness, suggests that As detoxification is prioritized over metabolic As cycling in the sediments. Collectively, the data point

\section{N. R. Posth \\ Department of Geosciences \& Natural Resource Management, Geology Section, University of Copenhagen, Øster Voldgade 10, 1350 Copenhagen K, Denmark}

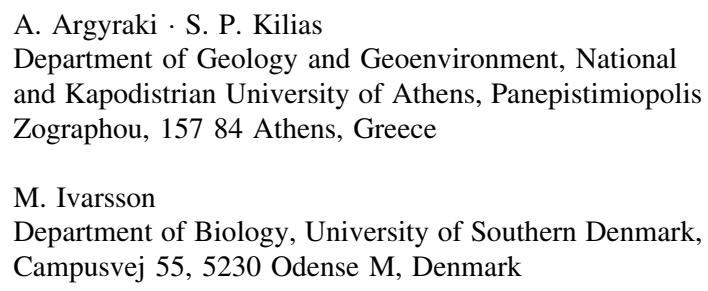


to redox control on $\mathrm{Fe}$ and $\mathrm{S}$ mineralization as a decisive factor in the regulation of high affinity phosphate uptake and As cycling gene content in shallow submarine hydrothermal ecosystems along the HVA.

Keywords Arsenic biogeochemistry $\cdot$ Arsenic speciation · Phosphate biogeochemistry .

Hydrothermal activity

\section{Introduction}

Arsenic (As) is ubiquitous in the marine and terrestrial biosphere, where it exists primarily as inorganic arsenate-As(V), arsenite-As(III) and as a variety of arsenic sulfides (As-S) in oxic, anoxic and euxinic environments, respectively (Maher and Butler 1988; Cullen and Reimer 1989; Smedley and Kinniburgh 2002; O’Day et al. 2004; O'Day 2006; Henke 2009; Godelitsas et al. 2015). The ratio of As(III) to As(V) in oxygenated seawater is estimated to be $\sim 10^{-27}$ and rapidly increases with deoxygenation (Maher and Butler 1988; Smedley and Kinniburgh 2002). This has resulted in the spread of As resistance mechanisms in the simplest to the most complex organisms inhabiting both oxic and anoxic habitats exposed to $\mathrm{As}(\mathrm{V})$ and As(III). Organic forms of As mostly found in highly productive waters, are believed to decrease and enhance toxicity at various instances (Wilkin et al. 2003; Hoffmann et al. 2018; Chen et al. 2017), but are also thought to be quantitatively negligible relative to $\mathrm{As}(\mathrm{III})$ and $\mathrm{As}(\mathrm{V})$ enrichment in the natural environment (Smedley and Kinniburgh 2002).

The pervasive spread of As resistance genes in microbial lineages at the base of the tree of life (e.g., Gihring et al. 2003; Jackson and Dugas 2003), suggests exposure to As in the deep geological past (Chen et al. 2017; Tian and Luo 2017). This ancient interplay between life and As resulted in the biological innovation of resistance mechanisms whereby $\mathrm{As}(\mathrm{V})$ is reduced with unique cytoplasmic $\mathrm{As}(\mathrm{V})$ reductases to As(III), followed by extrusion via specific As(III) cell membrane protein transporters (Rosen 2002; Jackson and Dugas 2003; Cai et al. 2009; Dziubinska-Maciaszczyk et al. 2011; Rosen et al. 2011; Slyemi and Bonnefoy 2012a, b; Zhu et al. 2017). Importantly, the presence and expression of these detoxification pathways in recently evolved lineages, including the more complex eukaryotes (Mukhopadhyay et al. 2002; Rosen 2002; Harrington et al. 2008; Fu et al. 2009; Qin et al. 2009; Dziubinska-Maciaszczyk et al. 2011), highlights the fact that As continues to exert considerable pressure on modern biological organization.

Notably, the physical and chemical similarities shared between $\mathrm{As}(\mathrm{V})$ and phosphate has resulted in As(V) interfering with biological phosphate metabolism (Thiel 1988; Takahashi et al. 1990; Dyhrman and Haley 2011; Guo et al. 2011; Rosen et al. 2011; Tawfik and Viola 2011; Elias et al. 2012; Xu and Nussinov 2012). Consequently, low affinity membrane phosphate transporters (Pit) that constitutively transport phosphate into the cell in phosphate-replete settings (Lin et al. 2016), are incapable of distinguishing As(V) from phosphate (Elias et al. 2012). Chemolithoautotrophs and many marine Cyanobacteria inhabiting As-rich geothermal environments switch on a high affinity phosphate uptake system (Pst) when dissolved $\mathrm{As}(\mathrm{V})$ to phosphate ratios rise above a certain threshold (Dyhrman and Haley 2011; Elias et al. 2012). The Pst system is also expressed in phosphate-starved conditions, regardless of whether $\mathrm{As}(\mathrm{V})$ is present or absent (Thiel 1988; Guo et al. 2011; Karl 2014; Lin et al. 2016).

Despite the challenge of As toxicity, a peculiar but polyphyletic group of microorganisms conserve energy from As, by respiring $\mathrm{As}(\mathrm{V})$ to $\mathrm{As}(\mathrm{III})$ and by oxidizing $\mathrm{As}(\mathrm{III})$ back to $\mathrm{As}(\mathrm{V})$ in a variety of marine and terrestrial habitats (e.g., Mukhopadhyay et al. 2002; Smedley and Kinniburgh 2002; Oremland and Stolz 2003; Rosen 2002; Gihring et al. 2003; Jackson and Dugas 2003; Oremland and Stolz 2003; Saltikov and Newman 2003; Malasarn et al. 2004; Stauder et al. 2005; Silver and Phung 2005; Quéméneur et al. 2008; Cai et al. 2009; Fu et al. 2009; Henke et al. 2009; Newman et al. 2009; Qin et al. 2009; Dyhrman and Haley 2011; Dziubinska-Maciaszczyk et al. 2011; Rosen et al. 2011; Sánchez-Riego et al. 2014; Zhu et al. 2014, 2017; Gilhooly et al. 2014; Jiang et al. 2014; Rascovan et al. 2016).

A number of studies have identified and successfully characterized microbial communities thriving in hydrothermal vent fields impacted by some of the most elevated As concentrations (e.g., Dando et al. 1995; Bayraktarov et al. 2013; Giovannelli et al. 2013; Price et al. 2013a, b; Ruiz-Chancho et al. 2013; Gilhooly 
et al. 2014; Godelitsas et al. 2015; Callac et al. 2017). Nonetheless, a mechanistic understanding of how life copes with high As conditions, the chemical and physical processes that regulate dissolved As content, and the potentially biolimiting phosphate concentrations caused by coprecipitation with hydrothermal $\mathrm{Fe}(\mathrm{III})$ (oxyhydr)oxides (e.g., Feely et al. 1996, 1998; Wheat et al. 1996; Schaller et al. 2000; Hawkes et al. 2014), remain to be clarified for these environments.

Here, we demonstrate a link between two types of reactive minerals, Fe sulfide and $\mathrm{Fe}(\mathrm{III})$ (oxyhydr)oxides, and the scavenging of As and $\mathrm{P}$ across a transect of hydrothermally influenced sediments at Spathi Bay, on the coast of Milos Island, Greece (Fig. 1). In situ biogeochemical data are synthesized into a quantitative field-wide community composition model for the abundance of respiratory $\mathrm{As}(\mathrm{V})$ reductases ( $\operatorname{arr} A)$, As(III) oxidases (aoxB), the As(III) membrane extrusion genes ( $\operatorname{ars} B, a c r 3-1$ and $a c r 3-2)$ and high affinity phosphate uptake ( $p s t B$ ) gene content, relative to $S$ and Fe mineralogy.

\section{Study site}

Spathi Bay is located at $36^{\circ} 40^{\prime} \mathrm{N}, 24^{\circ} 31^{\prime} \mathrm{E}$ in the south east of Milos Island, on the Hellenic Volcanic Arc (HVA), in the Greek Cyclades of the Aegean Sea
(Fig. 1). Hydrothermal activity along the HVA is a result of the subduction of the African Plate underneath the Euroasian Plate (Kilias et al. 2013). The coast of Milos is recognized as one of the largest active, shallow submarine hydrothermal areas on Earth (Dando et al. 1995; Bayraktarov et al. 2013; Giovannelli et al. 2013; Price et al. 2013a, b; RuizChancho et al. 2013; Chi Fru et al. 2013; Gilhooly et al. 2014; Godelitsas et al. 2015), covering an estimated $\sim 35 \mathrm{~km}^{2}$ of the shallow seafloor (Price et al. 2013b) (Fig. 1). Here, hydrothermal activity is accompanied by the emission of $\mathrm{H}_{2} \mathrm{~S}-\mathrm{CO}_{2}$-As-rich fluids, along the entire HVA (Bayraktarov et al. 2013; Giovannelli et al. 2013; Price et al. 2013a, b; RuizChancho et al. 2013; Chi Fru et al. 2013; Gilhooly et al. 2014; Godelitsas et al. 2015; Callac et al. 2017), with ferruginous sediments dating back $\sim 2.0$ million years characterized by a high As anomaly (Chi Fru et al. 2013, 2015b, 2018).

Hydrothermal fluid emission on the shore of Milos Island has temperatures, $\mathrm{pH}$, salinity and $\mathrm{H}_{2} \mathrm{~S}$ concentration reaching $40-116{ }^{\circ} \mathrm{C}, 5.0,50 \%$ and $3.1 \mathrm{mmol}^{-1}$, respectively (Bayraktarov et al. 2013; Giovannelli et al. 2013; Price et al. 2013a, b; RuizChancho et al. 2013; Gilhooly et al. 2014; Godelitsas et al. 2015). Fluids emitted through unconsolidated sandy sediments produce up to $2.9 \times 10^{3} \mathrm{ppb}$ As at Palaeochori Bay and $5.9 \times 10^{3} \mathrm{ppb}$ As at Spathi Bay

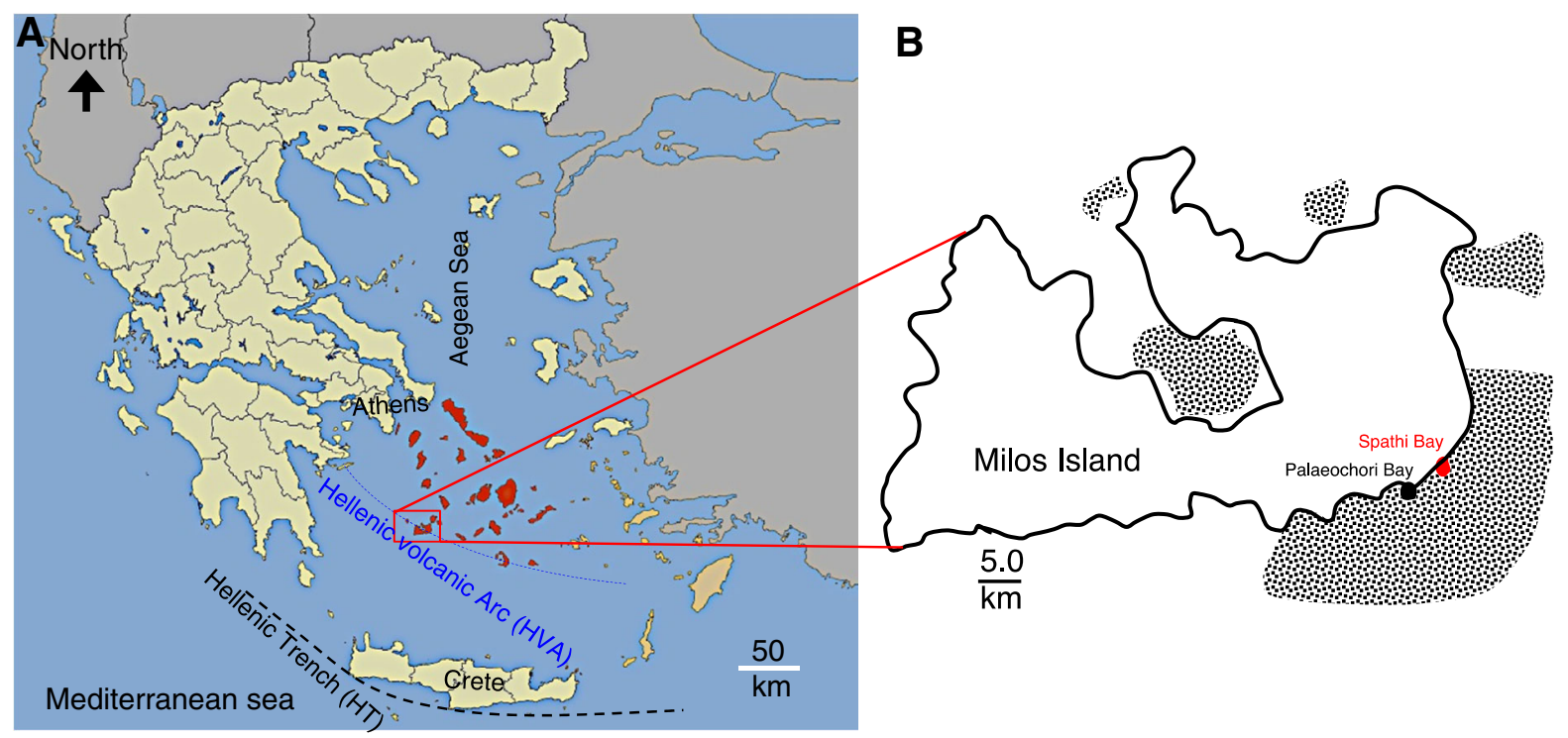

Fig. 1 Location of field site in the Aegean Sea. a Location of Milos along the Hellenic Volcanic Arc (HVA). b Sampling site. Dots are areas where shallow submarine activity has been located on the seafloor (Dando et al. 1995) 
(Giovannelli et al. 2013; Price et al. 2013a, b; RuizChancho et al. 2013). Indeed, the Spathi Bay hydrothermal fluids are up to $\sim 3000$ times richer in As than local seawater, making them some of the richest As fluids known for any hydrothermal emissions on Earth (Breuer and Pichler 2013). The anoxic hydrothermal solutions mixing with oxygenated seawater contain mainly $\sim 49 \%-\mathrm{As}(\mathrm{III})$ and $9 \%-\mathrm{As}(\mathrm{V})$, the remainder identified as various dissolved thioarsenic sulfide species (Giovannelli et al. 2013; Price et al. 2013a, b; Ruiz-Chancho et al. 2013). These fluids precipitate concentric, colorful, sand-grain coatings around the vent centers, and are broadly characterized by yellow-orange As sulfide patches, white sulfursilica biomats, and outward-bound brown-capped sediments comprised mostly of $\mathrm{Mn}$ oxides and
$\mathrm{Fe}(\mathrm{III})$ (oxyhydr)oxides sand coatings (Dando et al. 1995; Kilias et al. 2013; Giovannelli et al. 2013; Price et al. 2013a, b; Ruiz-Chancho et al. 2013; Callac et al. 2017; Fig. 2). Sand-capped sediments, which lack gas bubbles, seafloor hydrothermal seeps and the colorful sand coatings and biomats, rim the active venting centers (Callac et al. 2017).

\section{Methods}

\section{Sampling}

Seawater samples were collected at $1 \mathrm{~m}$ intervals down to the seafloor depth of $12.5 \mathrm{~m}$, using a Niskin Bottle that was thoroughly rinsed with water from the

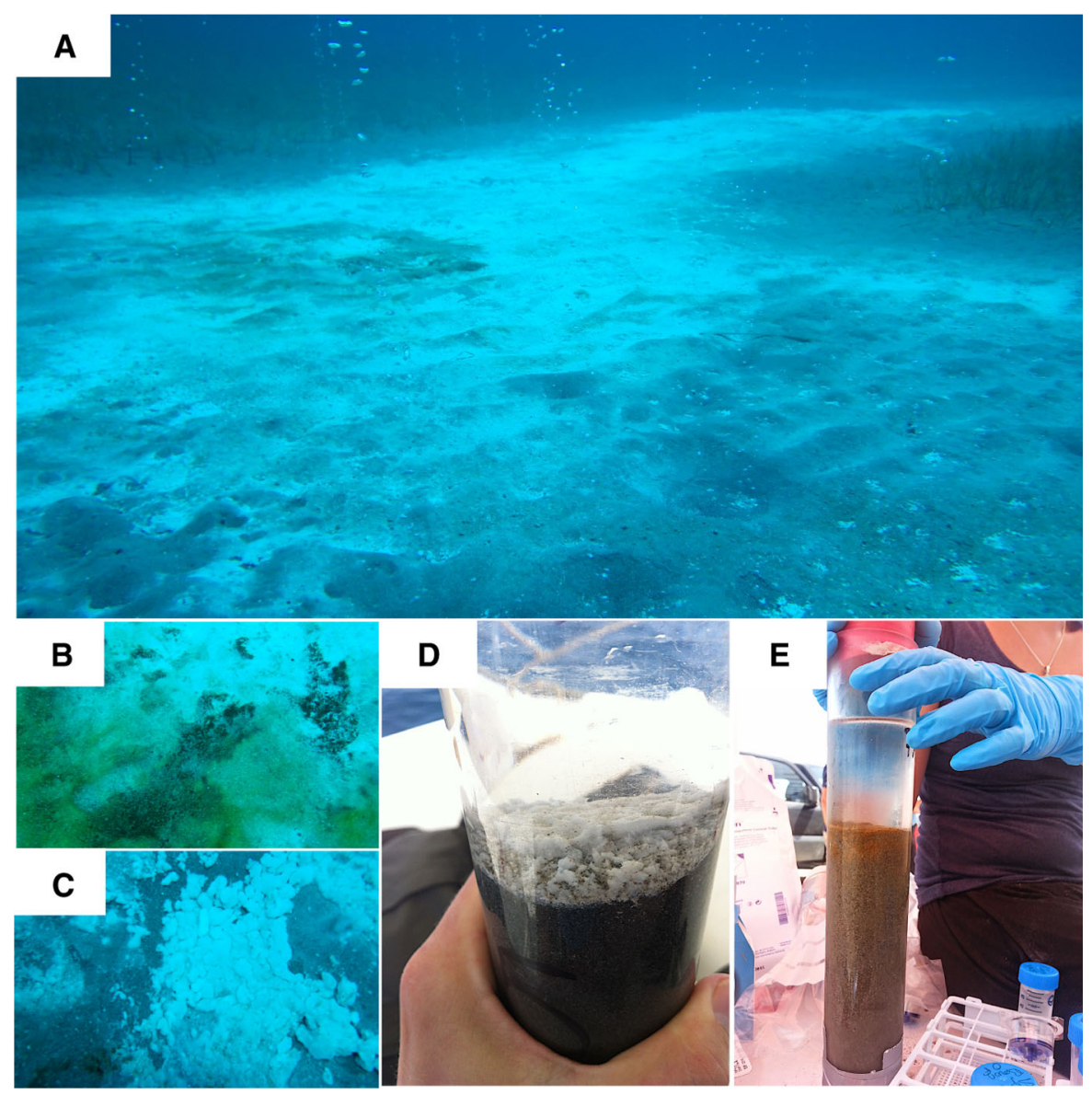

Fig. 2 Sample collection. a Seafloor diffused hydrothermal activity characterized by gas bubbles and the seafloor white and brown mats. b Close up view showing the sharp boundary between the white and brown seafloor deposit. $\mathbf{c}$ Close up view of white deposit on the seafloor. d Push core sample for the white-capped sediment. e Push core sample for the browncapped sediment 
sampled-depth, $500 \mathrm{ml}$ of which was filtered through $0.22 \mu \mathrm{m}$ nylon membrane filters (Maine Manufacturing). In addition, $25 \mathrm{ml}$ unfiltered seawater was mixed with $96 \%$ ethanol in $50 \mathrm{ml} \mathrm{Falcon}{ }^{\circledR}$ tubes. All samples were immediately frozen and transported on dry ice for molecular analyses. Replicate push core samples were collected and processed as previously described (Callac et al. 2017). Briefly, in a field anaerobic glove bag (Captair $^{\circledR}$ Pyramid glove Bag, Cole-Parmer), under a $\mathrm{N}_{2}$ atmosphere, sediment cores were sectioned with sterile disposable plastic spatulas into $2 \mathrm{~cm}$ slices and stored in $50 \mathrm{ml} \mathrm{Falcon}{ }^{\circledR}$ tubes. The tubes were immediately frozen on dry ice, shipped to the laboratory and stored at $-20{ }^{\circ} \mathrm{C}$, together with the water samples. Samples for chemical analysis were put in sterile anoxic bags, flushed with $\mathrm{N}_{2}$ and preserved on dry ice during transportation.

\section{Sediment porewater and seawater chemistry}

Seawater oxygen content, electrical conductivity, $\mathrm{pH}$ and temperature were measured during sampling with microprobes attached to the Niskin Bottle sampler. Sediment porewater for total trace element content was extracted under a nitrogen atmosphere from sectioned cores by centrifugation for $10 \mathrm{~min}$ at $6439.2 \mathrm{~g}$ (Callac et al. 2017). The recovered water was filtered through $0.2 \mu \mathrm{m}$ polyethersulfone (PES) membrane filters $\left(\right.$ Sarstedt ${ }^{\circledR}$ ) prior to analysis. Retrieved porewater was low for several samples. These samples, together with the overlying seawater samples, were acidified to a final $\mathrm{HNO}_{3}$ concentration of $0.28 \mathrm{~mol} \mathrm{l}^{-1}$ with ultra-pure grade $\mathrm{HNO}_{3}$. The acidified solutions were further diluted 1000 -fold in $0.28 \mathrm{~mol}^{-1} \mathrm{HNO}_{3}$ acidified milli-Q $\mathrm{H}_{2} \mathrm{O}$ and analysed by inductively coupled plasma-optical emission spectrophotometry (ICP-OES) for trace element composition. For porewater arsenite, arsenate and phosphate measurements, $10 \mathrm{~g}$ of wet sediment was diluted in $40 \mathrm{ml} \mathrm{MQ}-\mathrm{H}_{2} \mathrm{O}$ in a COY anaerobic chamber. After equilibration, $1.0 \mathrm{ml}$ of the settled solution was passed through a $0.2 \mu \mathrm{m}$ filter and analysed by the molybdate blue complexation reaction (Johnson 1971; Johnson and Pilson 1972; Dhar et al. 2004). Absorbances were obtained at $865 \mathrm{~nm}$ wavelength for the color complex formed on a Cary 50 Probe UV-vis spectrophometer. Porewater concentrations were deduced from linear plots of known concentrations of arsenate and phosphate standards plotted against their absorbances with
$\mathrm{R}^{2}=\sim 0.999$ (Johnson 1971; Johnson and Pilson 1972; Dhar et al. 2004). Values were reported as averages of duplicate measurements after accounting for the dilution factor.

\section{Sediment mineralogy}

Powder X-ray diffraction (PXRD), using a PANalytical Xpert-pro diffractometer, at room temperature, was used to analyse the mineralogical composition of sediments dried at $60{ }^{\circ} \mathrm{C}$ overnight and powdered in an agate mortar. The instrument was run at $45 \mathrm{kV}$ and $40 \mathrm{~mA}$ at $1.5406 \AA$ wavelength using $\mathrm{Cu}-\mathrm{K} \alpha$ radiation and Ni-filter. Samples were run between 5 and $80^{\circ}$ in step sizes of $0.017^{\circ}$ and scan step time of $50.1650 \mathrm{~s}$ in continuous scanning mode while rotating samples. Raman spectroscopy was performed using a confocal laser Raman spectrometer (LabRAM HR 800; Horiba), equipped with a multichannel air-cooled chargecoupled device detector as previously described (Chi Fru et al. 2013, 2016c). Spectral resolution was $\sim 0.3 \mathrm{~cm}^{-1} /$ pixel. Accuracy was determined by a repeated silicon wafer calibration standard at a characteristic Raman line of $520.7 \mathrm{~cm}^{-1}$.

Sediment reactive iron and reactive sulfide content

Sequential iron extraction was performed according to the method of Poulton and Canfield (2005) to separate six distinct Fe phases: (1) Fe carbonates, (2) $\mathrm{Fe}(\mathrm{III})$ oxyhydroxides, (3) magnetite, (4) hematite, some goethite and akaganéite, (5) poorly reactive sheet silicate $\mathrm{Fe}$, and (6) total sediment $\mathrm{Fe}$. These analyses were performed by sequential treatment of $50 \mathrm{mg}$ of oven-dried $\left(60^{\circ} \mathrm{C}\right)$ and powdered samples with $10 \mathrm{M}$ sodium acetate, sodium dithionite, ammonium oxalate, a second sodium dithionite extraction, followed by boiling in $12 \mathrm{M} \mathrm{HCl}$, and total dissolution with heat, nitric and hydrofluoric acid treatment, respectively (Poulton and Canfield 2005). Total Fe in these six fractions was measured by colorimetric UVvis spectrophometry using the ferrozine reaction (Stookey 1970; Viollier et al. 2000). Total sediment sulfide content was estimated following extraction by the cold chromium distillation method (Kallmeyer et al. 2004) to account for both pyrite and acid volatile sulfide, according to Cline and co-workers (Cline 1969). 
Molecular analysis

DNA extraction was performed in duplicates on $0.25 \mathrm{~g}$ of sediment, using the Mo Bio PowerSoil DNA kit (Carlsbad, CA) according to the manufacturer's instructions. Seawater DNA stored on filters was extracted using the MoBio PowerWater ${ }^{\circledR}$ DNA Isolation Kit (Carlsbad, CA) following the manufacturer's instructions. DNA from the seawater preserved in $96 \%$ ethanol solution was extracted, after centrifugation at $10,732 \mathrm{~g}$ for $30 \mathrm{~min}$, using the DNeasy ${ }^{\circledR}$ Blood and Tissue kit (Qiagen) as specified by the manufacturer.

Using a universal primer set targeting the $a \circ x B$ and Geobacteraceae-specific primers for the arrA, acr3-1, acr3-2 and pst genes and 16S rDNA (Table S1), qPCR was performed in 96-well plates in a CFX96 Touch $^{\mathrm{TM}}$ Real-Time PCR Detection System (C1000 Touch ${ }^{\text {TM }}$ Thermal, Cycler, Bio-Rad). The arrA and aoxB genes carry out respiratory $\mathrm{As}(\mathrm{V})$ reduction and $\mathrm{As}(\mathrm{III})$ oxidation, respectively, in prokaryotes (Oremland and Stolz 2003; Páez-Espino et al. 2009; Song et al. 2009; Kumari and Jagadevan 2016). The acr3-1 and acr3-2 genes, common in both prokaryotes and eukaryotes and the prokaryotic-specific ars $B$ gene, code for efflux proteins that pump As(III) out of cells during As detoxification (e.g., Oremland and Stolz 2003). The pst gene codes for high affinity phosphate uptake in microbial organisms and has been shown to be especially important for survival in As-rich phosphate-poor geothermal environments (e.g., Elias et al. 2012).

Individual gene quantification by qPCR was in final volumes of $25 \mu \mathrm{l}$, using the SsoAdvancedTM Universal SYBR ${ }^{\circledR}$ Green Supermix (Bio-Rad), following the manufacturer's recommendations. Samples contained $5 \mu \mathrm{l}$ of DNA ( $1 \mathrm{ng} / \mu \mathrm{l})$, specific primer set at appropriate concentrations and annealing temperatures (Table S1), in 35 cycle reactions. Standard curves were calibrated using ten-fold dilutions from pure cultures (Table S1). qPCR gene quantification was performed in triplicates in samples, standards, together with negative controls to check for laboratory contamination. The total gene copy numbers per gram of sediment or per litre of seawater was calculated from the triplicate sample averages as previously described (Callac et al. 2015, 2017). Geobacteraceae $16 \mathrm{~S}$ rRNA gene abundance was estimated according to the average of 4.1 for bacteria $16 \mathrm{~S}$ rRNA genes per cell (Lee et al. 2009; Callac et al. 2015, 2017). We assumed one copy per genome for the As and phosphate genes. Standard curves of ten orders of magnitude, determined from serially diluted DNA from pure cultures and quantified by NanoDrop spectrophotometry, were used to calculate gene abundances. The accepted efficiency of the qPCR data was determined to be $\geq 95 \%$ from the slope of the standard curves.

Statistical analysis

Multivariate statistical analysis was performed using the Minitab 17 statistical software with the aim to explore the association of genomic with sediment geochemical data. Principal component factor analysis with a varimax rotation was applied to the total dataset in order to create factors, each representing a cluster of interrelated variables. Factor analysis and cluster analysis using the average neighbor linkage measure were applied to the data after normal score transformation of the raw values. This ensured the normal distribution for variables and reduced the influence of high values on the output results. The selection of the optimum principal components was based on the scree plot, which is the graphical visualization of the relationship between the eigenvalues and the number of components. In this case, the cut-off was chosen at the point where the function displayed by the scree plot showed an elbow, allowing for the division of the major components from the trivial components. The distance measure used in cluster analysis was the Pearson correlation coefficient at $95 \%$ confidence level.

\section{Results and discussion}

Water column and sediment chemistry

Temperature, electrical conductivity (EC), oxygen concentration and $\mathrm{pH}$ of seawater along the $12.5 \mathrm{~m}$ depth profile to the seafloor over the two-day sampling period, averaged $24{ }^{\circ} \mathrm{C}(\mathrm{SD} \pm 0.4, \mathrm{n}=35), 59.01 \mathrm{mS}$ $\mathrm{cm}^{-1}(\mathrm{SD} \pm 0.07, \mathrm{n}=11), 9.4 \mathrm{mg} \mathrm{l}^{-1}(\mathrm{SD} \pm 0.16$, $\mathrm{n}=23)$ and $8.3(\mathrm{SD} \pm 0.012, \mathrm{n}=11)$, respectively. The alkali and alkaline Earth metals $\mathrm{K}, \mathrm{Mg}, \mathrm{Ca}$ and $\mathrm{Na}$, together with redox sensitive $\mathrm{S}$, were the most abundant elements in the sediment porewater 
(Table $\mathrm{S} 2$ ). $\mathrm{P}$ and $\mathrm{Pb}$ were low in all sediment types, depth and seawater, with $\mathrm{P}$ being predominantly below the ICP-OES detection limit of $2.0 \mathrm{ppb}$ in the sediment porewater and overlying seawater. The abundance of $\mathrm{K}$ in the Milos hydrothermal sediments has previously been attributed to silicate mineralization (Price et al. 2013a).

The highest porewater total As content (42.7 ppb) was recorded in the white-capped sediment at 14-16 cm depth, while concentrations in the brown/ sand-capped sediments were below detection at some depths, reaching a maximum of $0.6 \mathrm{ppb}$ in the browncapped sediments. Despite elevated sediment As concentration, seawater content above the sampled sediments was below the ICP-OES detection limit, with the exception of one positive outlier (Table S2). The trace metals $\mathrm{Cd}, \mathrm{Cr}$ and the biologically important trace nutrients, $\mathrm{Co}, \mathrm{Mo}, \mathrm{Cu}, \mathrm{Fe}, \mathrm{V}$ and $\mathrm{Ni}$ were depleted in the seawater column. The depletion of trace metals and nutrients was similar in the sediments. Cd was only detected in the white-capped sediments, while detectable Mo was mainly recorded in the brown- and sand-capped sediments. Below $10 \mathrm{~cm}$, Co was not detected in the brown-and sandcapped sediments. S was present in all samples and depths, including seawater, but decreased dramatically with depth in the brown-capped sediment, while the deepest section in the white-capped sediment that could be analysed, sustained high levels (Fig. 3a). However, porewater chemistry for the intermediate depths in the white-capped sediments could not be measured by ICP-OES, because too little water could be retrieved for analysis.

Comparative analysis suggests average porewater $\mathrm{S}$ content is several orders of magnitude above As, Fe and $\mathrm{Mn}$ concentrations in all sediment types, being most elevated in the white-capped sediment (Fig. 3bc). An above and below average positive linear correlation emerged between porewater $\mathrm{As}$ and $\mathrm{S}$ in the sulfide-rich and sulfide-depleted white-capped and brown/sand-capped sediments, with $\mathrm{R}^{2}$ values of 0.62538 and 0.45066 , respectively. These relationships indicate $a \sim 63$ and $45 \%$ variation in the sedimentary As content, related to $S$ in the whitecapped and brown/sand-capped sediments, respectively. A previously unknown robust positive correlation was observed between porewater As and $\mathrm{Mn}$ concentrations in all habitats $\left(\mathrm{R}^{2}=0.86248,0.88342\right.$ and 0.96749 ) for the white-, brown- and sand-capped sediments, corresponding to $\sim 86,88$ and $97 \%$ covariation between the variables, respectively. However, a linear correlation for porewater $\mathrm{As}$ and $\mathrm{Fe}$ became apparent only in the sand-capped sediments, with $\mathrm{R}^{2}$ values increasing in the order of 0.03404 , 0.46744 and 0.93176 for the white-, brown- and sandcapped sediments, respectively. These values, which correspond to 3, 47 and $93 \%$ related variation between As and $\mathrm{Fe}$ along the sampled transect, suggest porewater in the three sediment types are chemically distinct, in agreement with previous findings (Callac et al. 2017).

Sediment sulfide and Fe(III)(oxyhydr)oxides mineralization

Maximum total sediment sulfide concentration across the study transect reaches $9.5 \times 10^{5} \mu \mathrm{M} \mathrm{g}^{-1}$ of sediment at $6-8 \mathrm{~cm}$ in the white-capped deposit (Fig. 3d), consistent with a black sulfide color (Fig. 2d), odour and the detection of pyrite and marcasite by Raman spectroscopy (Fig. 4a). Sulfide declines with depth in the brown-capped sediment, similar to total porewater $\mathrm{S}$ concentration (Fig. 3a, d). A decrease in average sulfide content by 4.2 and 48.1 times in the brown- and sand-capped sediments relative to the white-capped sediment, respectively, suggests a declining sulfide front away from the hydrothermal center (Fig. 3d). Moreover, while pyrite and marcasite are below detection in the brown and sand-capped sediments, Fe(III)(oxyhydr)oxides concentration generally increases from the white-capped deposit to the sand-capped setting (Fig. 3d).

Total sediment As and $\mathrm{P}$ along this sulfide gradient, covary with a linear correlation fit of $\mathrm{R}^{2}=0.82$ (Fig. 3e). A similar observation in the Pacific Ocean water column (Santosa et al. 1997), hints that the global sediment As and $\mathrm{P}$ cycles are not mutually exclusive. Calculated reactive $\mathrm{S}$ and $\mathrm{Fe}$ ratios (Fig. 3f) indicate that a robust inverse relationship between sulfide and $\mathrm{Fe}$ (III)(oxyhydr)oxides production plays a key role in As and $\mathrm{P}$ mobility across the studied transect. As-sulfides, and up to $1.3 \mathrm{wt} \% \mathrm{Fe}$ (III)(oxyhydr)oxides have been reported in these sediments (Price et al. 2013b; Ruiz-Chancho et al. 2013). Chemical extraction of Fe(III)(oxyhydr)oxides phases (Table 1), and hematite and potential goethite phases detected by Raman spectroscopy (Fig. 4b), suggest that $\mathrm{Fe}(\mathrm{III})$ (oxyhydr)oxides are a potent $\mathrm{P}$ sink, but a 

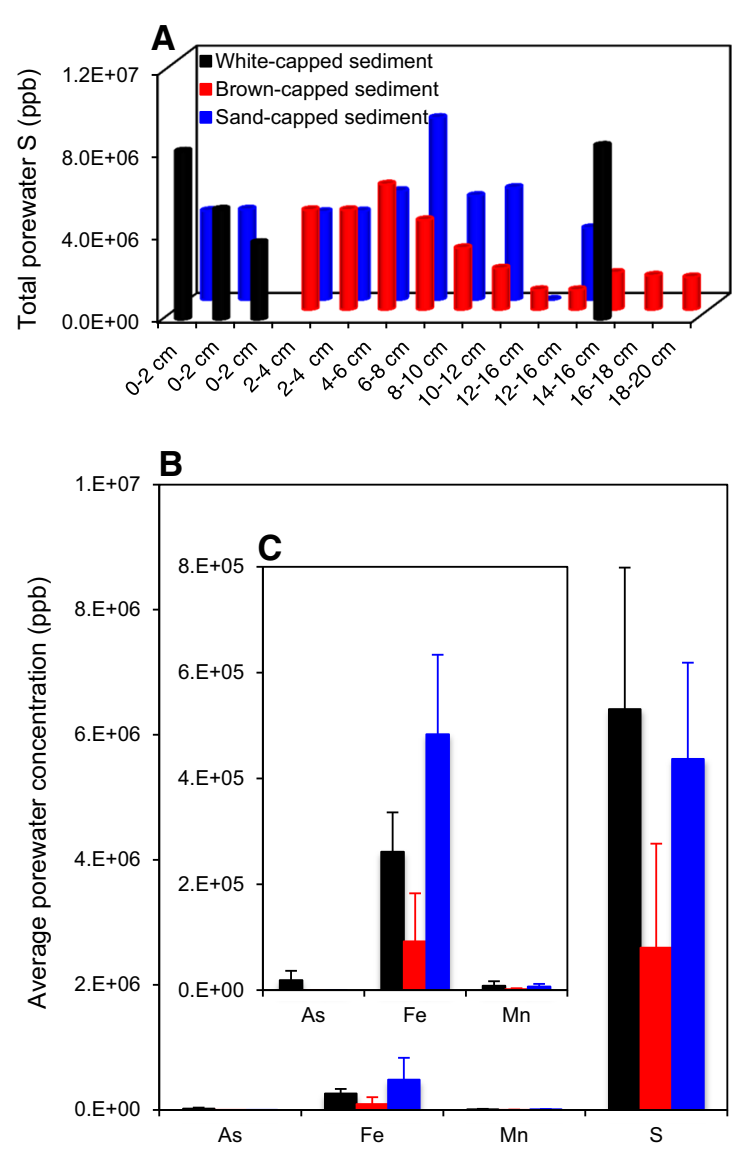

Fig. 3 Total sediment sulfide obtained by the $\mathrm{Cr}$ distillation method and average porewater ICP-OES concentrations of S, $\mathrm{Mn}, \mathrm{Fe}$ and $\mathrm{As}$ in sediment core down to $20 \mathrm{~cm}$. a Total porewater sulfur versus depth. b Average porewater S, Mn, Fe and As. c Magnification of average porewater $\mathrm{Mn}, \mathrm{Fe}$ and $\mathrm{As}$

relatively weaker As sink in the sediments dominated by quartz (Fig. 4c). Although they vary in amplitude, the difference in the ratio of $\mathrm{P}$ to As associated with $\mathrm{Fe}(\mathrm{III})$ (oxyhydr)oxide distribution across the sediment types is nearly constant (Table 1), similar to their total sediment content (Fig. 3e).

Of all the Fe(III)(oxyhydr)oxide phases, magnetitelike Fe content is low in all habitats (Table 1; Fig. S1). Potential Fe carbonates are $\sim 5$ times higher in the white-capped sediments than in the brown-/sandcapped sediments (Table 1), where they decrease with depth. To the contrary, Fe associated with Fe(III)oxyhydroxides are over 2-4 times greater in the brown-/ sand-capped sediment than they are in the whitecapped sediment, with the sand-capped samples having the most elevated concentrations (Table 1).

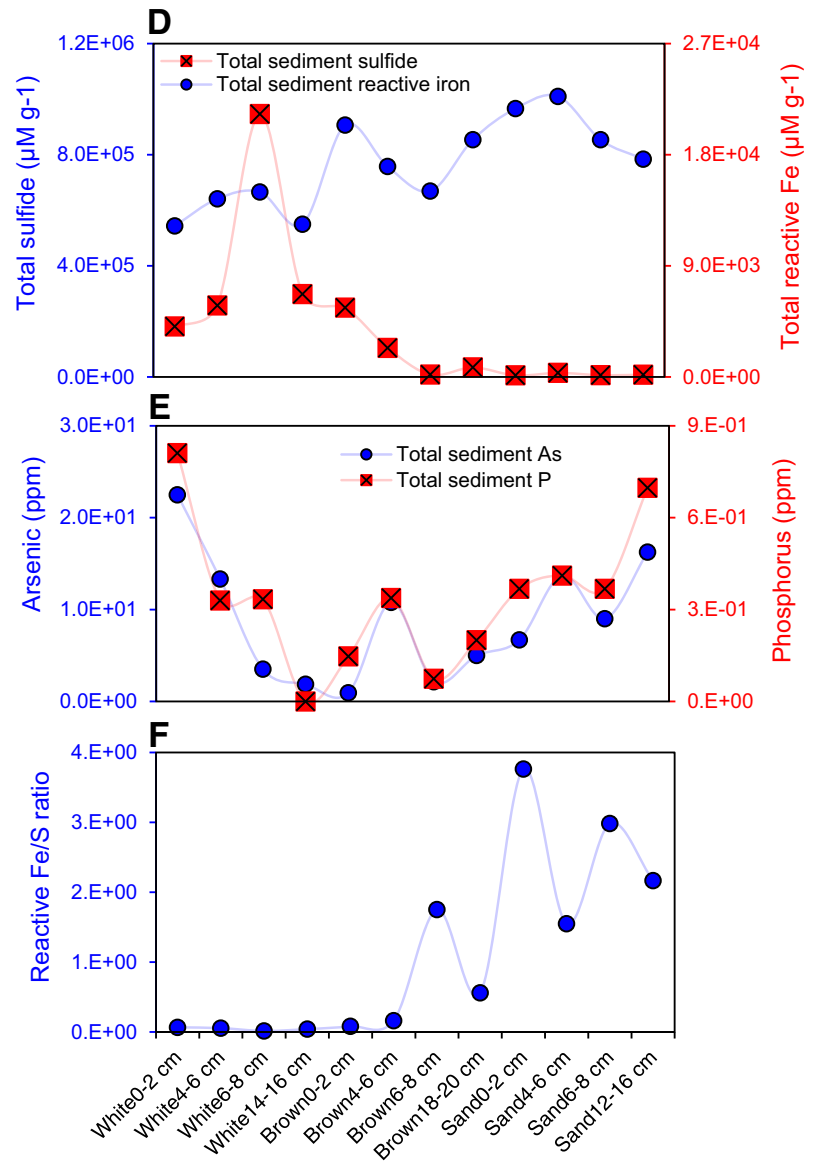

content from (b). Bars are standard deviation from the mean. d Total sediment sulfide and Fe versus depth and habitat. e Total sediment As and $\mathrm{P}$ versus depth and habitat. $\mathbf{f}$ Total reactive Fe (Fe(III)(oxyhydr)oxides) to total reactive sediment sulfide content plotted against habitat and sediment depth

Hematite, magnetite and sheet silicate Fe (phyllosilicate clay minerals) are evenly distributed throughout the various habitats and depths (Fig. S1).

Total sediment As content peaked close to the seafloor in the white-capped sediments, before decreasing with depth. For example, up to 12 times lower As concentrations are recorded at $6 \mathrm{~cm}$ than in the $0-2 \mathrm{~cm}$ depths (Table 1). No distinct trends were obvious in the brown-/sand-capped sediments. At no point did the estimated

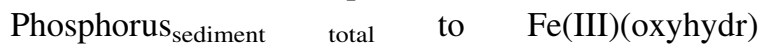
oxide $_{\text {sediment total }}+$ Phosphorus $_{\text {sheet silicate bound total }}$ ratios exceed 1, suggesting that most $\mathrm{P}$ in the sediments is adsorbed to Fe(III)(oxyhydr)oxides and clayey silicate minerals. To the contrary, Arsenic $_{\text {sediment total }}$ to $\mathrm{Fe}(\mathrm{III})$ (oxyhydr)oxide sediment total + 
Fig. 4 Raman

mineralogical analysis.

a Raman spectra for

marcasite intergrowth in

pyrite in the white-capped

sediment. b Raman spectra

for Fe oxides phases.

c Raman spectrum for quartz
A

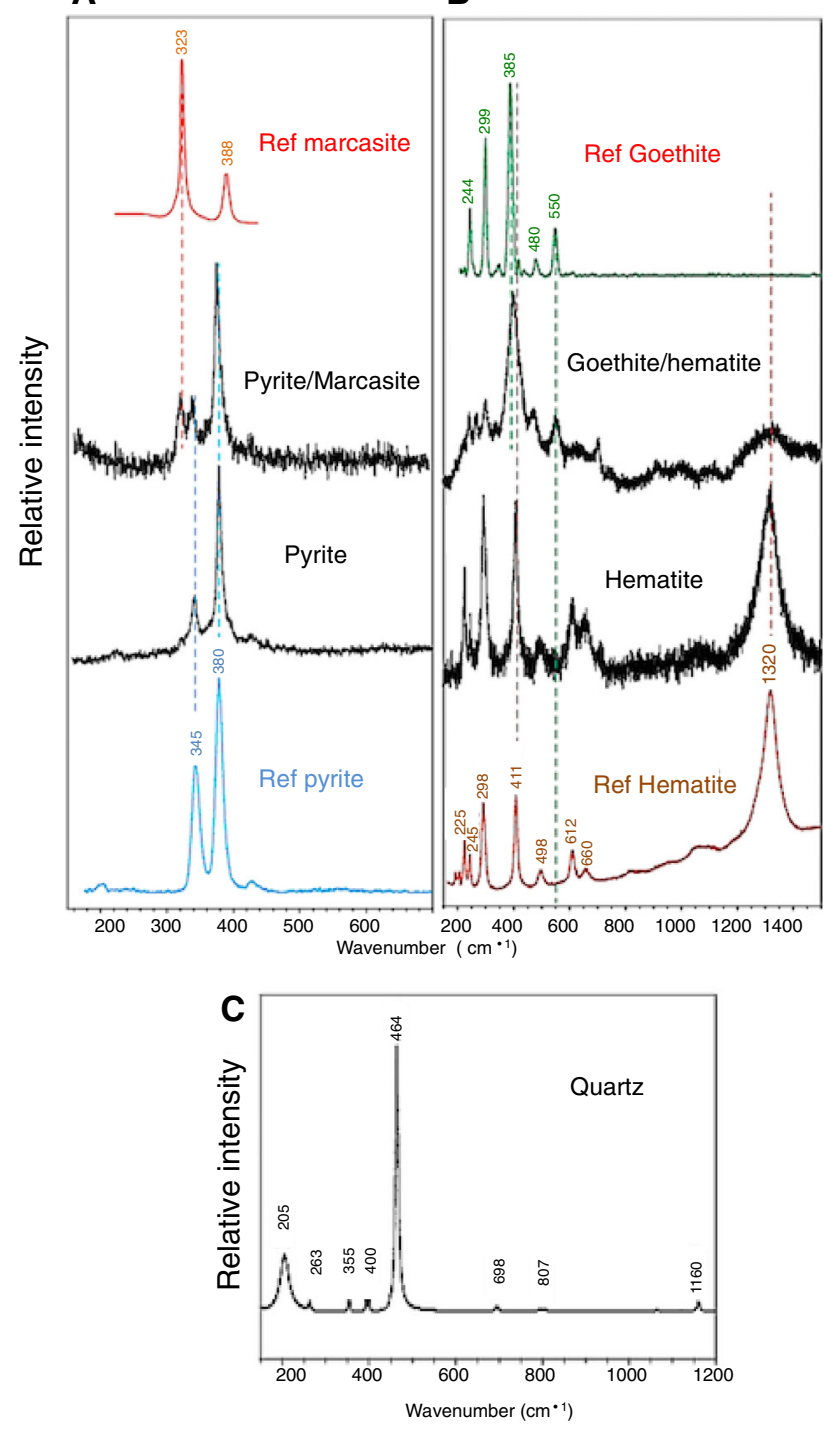

Arsenic $_{\text {sheet silicate bound total }}$ ratios were consistently $>1$, indicating the presence of As sinks in the sediments other than $\mathrm{Fe}(\mathrm{IIII})($ oxyhydr) oxides and sheet silicates. Our data, together with past mineralogical evidence, suggests these As sinks are most likely As-sulfides and Mn oxides. Both As sulfides and Mn oxides are known to prevail in this system and are discussed further below. XRD analysis revealed the ubiquity of the prominent marine Mn oxide mineral, birnessite, at all depths (Callac et al. 2017).

Indeed, $\mathrm{Mn}, \mathrm{Fe}$ and $\mathrm{S}$ chemistry are the main chemical components that strongly influence environmental As mobility (Takamatsu et al. 1985; Cullen and
Reimer 1989; Dando et al. 1995; Santosa et al. 1997; Ouvrard et al. 2002; Smedley and Kinniburgh 2002; Dixit and Hering 2003; O'Day et al. 2004; O'Day 2006; Maity et al. 2005; Lafferty et al. 2011; Breuer and Pichler 2013; Chi Fru et al. 2013; Dekov et al. 2013; Giovannelli et al. 2013; Gilhooly et al. 2014; Kilias et al. 2013; Price et al. 2013a, b; Ruiz-Chancho et al. 2013; Villalobos et al. 2014; Godelitsas et al. 2015). Mn oxides specifically oxidize As(III) and then adsorb and precipitate the resulting As(V) (Takamatsu et al. 1985; Ouvrard et al. 2002; Maity et al. 2005; Lafferty et al. 2011; Villalobos et al. 2014). Our data suggest a strong correlation between porewater $\mathrm{Mn}$ content and As, with the Mn oxide birnessite found at 


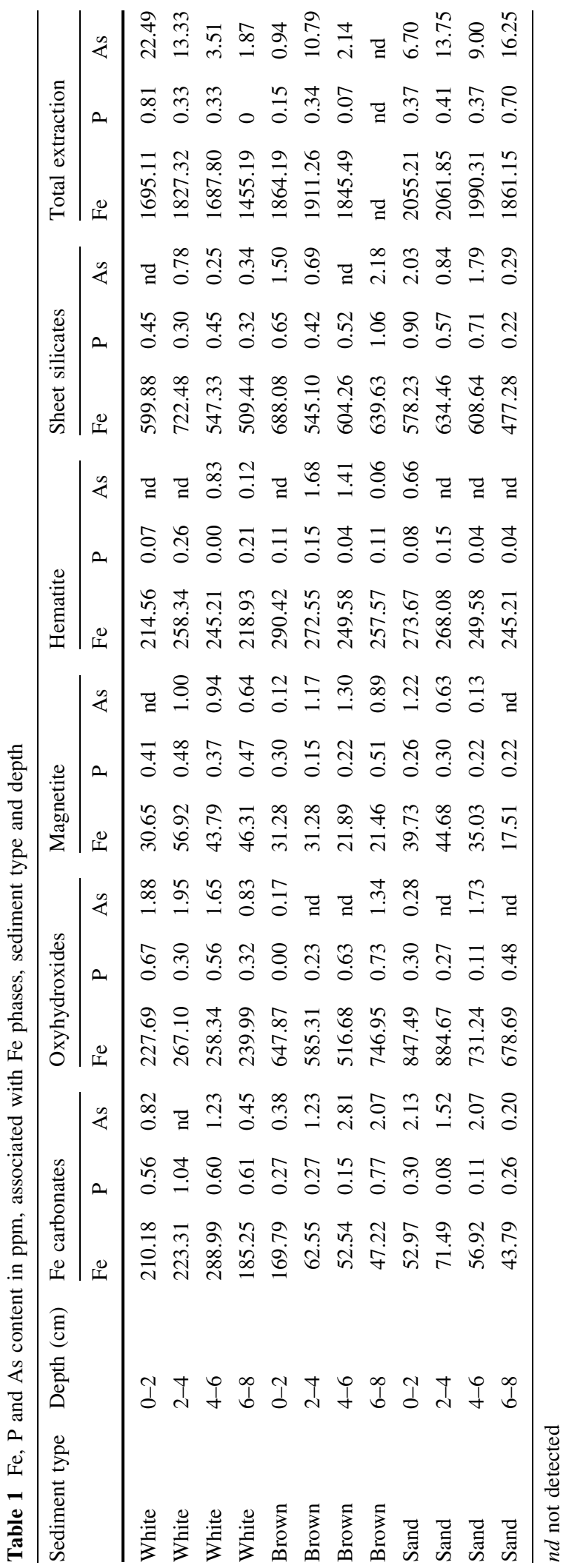

all sampled depths and habitats, recognized to be a strong As sink (Takamatsu et al. 1985). However, the consistent relationship that emerged between porewater Mn and As within and between habitats, implies that while Mn may be generally important for dissolved porewater As behaviour, it likely cannot account for As variability between sites.

$\mathrm{Fe}(\mathrm{III})$ (oxyhydr)oxides on their part are a well described As sink, resulting in their widespread application in the remediation of As-impacted waters (Cullen and Reimer 1989; Smedley and Kinniburgh 2002; Dixit and Hering 2003; Henke et al. 2009). There is therefore a general consensus that where $\mathrm{Fe}(\mathrm{III})$ (oxyhydr)oxides form, they coprecipitate As in its +3 and +5 oxidation states (Cullen and Reimer 1989; Smedley and Kinniburgh 2002; Henke et al. 2009; Kilias et al. 2013; Chi Fru et al. 2015a; Hemmingsson et al. 2018). The increase in $\mathrm{Fe}(\mathrm{III})$ (oxyhydr)oxides precipitation from the whitecapped hydrothermal center to the bordering sandcapped sediment, counterbalanced by a drop in sulfide production (Fig. 3d, f), is therefore expected to be important for dissolved As mobility. The role of As sulfide precipitation in the global regulation of As mobility is less discussed, although reactive $\mathrm{S} / \mathrm{Fe}$ ratios have been implicated as a possible indicator (O’Day et al. 2004; O’Day 2006). Environmental As and $\mathrm{S}$ chemistry are tightly coupled, such that sulfide production always results in the formation of As sulfides (Cullen and Reimer 1989; Smedley and Kinniburgh 2002; Stauder et al. 2005; Henke et al. 2009; Kilias et al. 2013; Chi Fru et al. 2015a; O’Day et al. 2004; O'Day 2006; Wilkin et al. 2003). Moreover, when sulfide production increases, it is commonly accepted that the accompanying precipitation of Fe sulfides hinder or outcompete the deposition of Fe(III)(oxyhydr)oxides (Canfield 1998; Poulton and Canfield 2011). This is consistent with the inverse relationship that emerged between total sulfide and $\mathrm{Fe}(\mathrm{III})$ (oxyhydr)oxides concentrations. In situ chemical data had long since shown that sulfide minerals quickly precipitate around hydrothermal vents, while $\mathrm{Fe}(\mathrm{III})$ (oxyhydr)oxides dispersal increases further away (Poulton and Canfield 2011; Chi Fru et al. 2015a). This is also coherent with our data.

In anoxic settings with $\mathrm{pH}<6, \mathrm{As}(\mathrm{V})$ is often preferentially coprecipitated with $\mathrm{Fe}(\mathrm{III})$ (oxyhydr)oxides at the expense of As(III) which preferably adsorbs onto $\mathrm{Fe}(\mathrm{III})$ (oxyhydr)oxides at $\mathrm{pH}>7$ (Dixit and 
Hering 2003). However, As(V) is not stable in sulfidicanoxic environments where As(III) predominates (Cullen and Reimer 1989; Smedley and Kinniburgh 2002; Henke et al. 2009). This is the case for the sulfidic-anoxic hydrothermal fluid emanations at Milos where As(III) and As(V) constitute $\sim 49$ and $9 \%$ of total As concentration, respectively, with various As sulfides making up for the remainder (Ruiz-Chancho et al. 2013). Taken together, As sulfide formation controls dissolved As content in sulfidic, low pH settings (Cullen and Reimer 1989; Giovannelli et al. 2013; Smedley and Kinniburgh 2002; Henke et al. 2009; Dekov et al. 2013; Price et al. 2013a, b; Ruiz-Chancho et al. 2013; Gilhooly et al. 2014; Godelitsas et al. 2015). In the presence of sulfide, dissolved thioarsenic As sulfides species are formed (Wilkin et al. 2003; Stauder et al. 2005; Henke et al. 2009) and have been shown to constitute $\sim 40 \%$ of the hydrothermal emissions on the coast of Milos Island (Ruiz-Chancho et al. 2013). This observation provides an important explanation for the higher total As concentration recorded in the white-capped sulfiderich sediments (Fig. 3e).

The orange-yellow sediments that are typically located in the center of the sampled transect, were absent at time of sampling. These have been described to be composed mainly of As sulfides (Gilhooly et al. 2014) on the basis of their easily recognizable bright orange and yellow colors. However, recent chemical characterization of these sediments, reveal elemental and impure sulfur (Godelitsas et al. 2015). The white patches are famously associated with white elemental sulfur produced via bacterial oxidation of sulfide (Gilhooly et al. 2014). Our results show that the whitecapped sediments are sulfide-rich and precipitate typical sulfide minerals. Moreover, the brown-capped sediments appear to also contain a significant amount of sulfide that decreases with depth. Further, sediment physicochemical conditions and thermodynamic constraints suggest conditions appropriate for the formation of the typical orpiment-like minerals common in the sulfide-rich settings on the HVA (Kilias et al. 2013; Giovannelli et al. 2013; Price et al. 2013a; RuizChancho et al. 2013; Gilhooly et al. 2014). For example, empirical and theoretical studies link major orpiment production in shallow hydrothermal sediments to local temperatures of $<100{ }^{\circ} \mathrm{C}$ and reducing conditions, along a wide $E h-p H$ range (Breuer and Pichler 2013; Dekov et al. 2013). The formation of realgar $\left(\mathrm{As}_{4} \mathrm{~S}_{4}\right)$ occurs occasionally at $\mathrm{T}=25^{\circ} \mathrm{C}$, within a narrower $E h-p H$ range (Dixit and Hering 2003). Porewater temperatures in the white-capped patches at Spathi Bay average $62-80{ }^{\circ} \mathrm{C}$ relative to a maximum of $81{ }^{\circ} \mathrm{C}$ for the orange and yellow patches (Price et al. 2013b). Moreover, the white deposits have a porewater $\mathrm{H}_{2} \mathrm{~S}$ content in the range of 0.31-2.89 mM, pH 4.8-5.7, compared to $\mathrm{H}_{2} \mathrm{~S}$ levels of $<0.01-1.96 \mathrm{mM}$ and $\mathrm{pH} 5.2-5.8$ in the orpimentrich orange and yellow sediments (Giovannelli et al. 2013). The precipitation of pyritic minerals in the white-capped sediment (Fig. 4a) is expected to scale linearly with As sulfide, arsenopyrite and arsenian pyrite formation (Cullen and Reimer 1989; Smedley and Kinniburgh 2002; Henke et al. 2009). Also, linear dissolution of orpiment along an increasing $\mathrm{pH}$ gradient coupled to oxidation by $\mathrm{Fe}$ (III)(oxyhydr)oxides (Lengke et al. 2009), likely accounts for the restriction of orpiment closer to the acidic-sulfiderich-Fe(III)(oxyhydr)oxide-poor vents. For example, $\mathrm{pH}$ increases from $\sim 5$ close to the vents to $\mathrm{pH} 8$ in the peripheral non-hydrothermally active sediments rich in $\mathrm{Fe}(\mathrm{III})$ (oxyhydr)oxides (further discussed below).

By coupling As speciation data obtained by X-ray Adsorption Near Edge Spectroscopy (XANES) to theoretical models, it was proposed that sulfide to $\mathrm{Fe}(\mathrm{III})$ (oxyhydr)oxide ratios in sediments and aquifers control As mobility (O'Day et al. 2004). The high sulfide system apparently drove the precipitation of orpiment (O'Day et al. 2004). Further, orpiment production coincides with high reactive $\mathrm{S} / \mathrm{Fe}$ ratio settings because elevated $\mathrm{H}_{2} \mathrm{~S}$ concentrations stabilize orpiment (O'Day et al. 2004; O'Day 2006). In these habitats, As sulfides form more rapidly relative to Fe(III)(oxyhydr)oxides (O’Day et al. 2004; O’Day 2006) and above a certain reactive $\mathrm{S} / \mathrm{Fe}$ ratio threshold, orpiment becomes saturated in the aqueous phase (O'Day et al. 2004; O'Day 2006). The latter view provides additional justification for the specific correlations seen between porewater As and $\mathrm{S}$ in the high sulfide sediment. It also justifies the strong porewater As to $\mathrm{Fe}$ linear correlation in the sulfide-poor$\mathrm{Fe}(\mathrm{III})$ (oxyhydr)oxide-rich sediments relative to the sulfide-rich-Fe(III)(oxyhydr)oxide-poor settings. 
Porewater arsenate, arsenite and phosphate geochemistry

As discussed above, Fe(III)(oxyhydr)oxides are expected to become a strong As and phosphate sink away from the white-capped deposit. In the whitecapped deposit, sulfide minerals will predominate As scavenging, but not phosphate burial, because sulfide minerals do not typically bind phosphate (e.g., Poulton and Canfield 2006; Brock and Schulz-Vogt 2011). Moreover, in Spathi Bay, we observed an increasing linear correlation between porewater $\mathrm{As}$ and $\mathrm{Fe}$ concentrations moving outwards from sulfide-rich white-capped sediments. In the sand-capped reference sediment we observed a maximum covariation between As and $\mathrm{Fe}$ of $93 \%$. This suggests that Fe(III) (oxyhydr)oxides are only likely to become a potent As sink when sulfide concentrations are low. Consistent with this observation, dissolved phosphate concentrations in Spathi Bay were highest in the sulfide-rich sediments and lowest in the Fe(III)(oxyhydr)oxiderich deposits.

Porewater As(III), As(V) and phosphate content agree with total As dynamics quantified by ICP-OES; i.e., being variable and significantly elevated in the white-capped sediment porewater compared to the brown-/sand-capped deposits (Fig. 5a-c; Table S2). Prominent but variable As(III)/As(V) ratios suggest the white-capped sediments are the most reducing of the three habitats (Fig. 5d-f), an observation consistent with their location in the hydrothermal venting center and high sulfide content (Fig. 3d). Comparably, porewater $\mathrm{As}(\mathrm{V}) / \mathrm{phosphate}$ ratios are generally higher in the white-capped sediment, but negligible across to the sand-capped deposit (Fig. 5e-f).

Phosphate is essential for all life and is believed to have regulated primary productivity through Earth's history (Reinhard et al. 2017). Crucially, most shallow submarine hydrothermal vent fluids are generally depleted in P, implying that unlike As, hydrothermal fluids are not a major $\mathrm{P}$ source but rather a strong seawater P sink (Wheat et al. 1996; Edmonds and German 2004; Poulton and Canfield 2006; Hawkes et al. 2014). Indeed, significant variation in As and $P$ concentrations through Earth's geological history have been linked to changing levels of submarine hydrothermal influence, $\mathrm{Fe}(\mathrm{III})$ (oxyhydr)oxide precipitation and sulfide content (Poulton and Canfield 2011; Chi Fru et al. 2015a; Reinhard et al. 2017; Chi
Fru et al. 2016a; Hemmingsson et al. 2018). Importantly, shallow submarine hydrothermal activity in the modern oceans are suggested to account for up to $57 \%$ of global hydrothermal $\mathrm{P}$ removal from the ocean via $\mathrm{Fe}(\mathrm{III})$ (oxyhydr)oxide precipitation (Hawkes et al. 2014). This is a significant value, given that shallow submarine hydrothermalism represents $<10 \%$ of global hydrothermal fluid emission on the modern seafloor (Hawkes et al. 2014).

Our results provide important support for quantitative removal of $\mathrm{P}$ by $\mathrm{Fe}(\mathrm{III})$ (oxyhydr)oxides in shallow submarine hydrothermal systems, hinting for the first time that the As-impacted fluids create severe porewater $\mathrm{P}$ deficiency in the affected sediments. Despite the total sediment As concentrations being over 40 times above $\mathrm{P}$, most $\mathrm{P}$ is preferentially bound to $\mathrm{Fe}(\mathrm{III})$ (oxyhydr)oxides. This observation is in agreement with previous studies that experimentally predicted that As enhances the affinity of $\mathrm{P}$ for $\mathrm{Fe}(\mathrm{III})$ (oxyhydr)oxides (Chi Fru et al. 2016b; Hemmingsson et al. 2018). Importantly, the lack of variability of this reactive $\mathrm{Fe}$ associated $\mathrm{P}$ across habitats (Table 1), indicates dissolved $\mathrm{P}$ is undersaturated at all sites analysed. $\mathrm{P}$ being below the detection limit of $2.0 \mathrm{ppb}$ in the overlying seawater P source, is in support of this hypothesis, as seawater $\mathrm{P}$ and dissolved sediment content are tightly linked. Further, the correlation of total sediment $\mathrm{P}$ with total sediment As concentrations (Fig. 3e) is consistent with the view that dissolved As impacts $\mathrm{P}$ scavenging by Fe(III)(oxyhydr)oxides (Chi Fru et al. 2016b). Unlike $\mathrm{Fe}(\mathrm{III})$ (oxyhydr)oxides, sulfide minerals are not known to bind phosphate (Poulton and Canfield 2006; Reinhard et al. 2017). This behaviour is consistent with the superior levels of phosphate detected in the Fe sulfide-rich white-capped sediment porewaters (Fig. 5c), relative to the brown-/sandcapped sediments rich in Fe(III)(oxyhydr)oxides. Data therefore suggest sulfide promotes dissolved $\mathrm{P}$ bioavailability by stimulating preferential precipitation of Fe sulfides instead of the Fe(III)(oxyhydr)oxide phosphate sink.

In agreement with Hawkes et al. (2014), we confirm that hydrothermal $\mathrm{Fe}(\mathrm{III})$ (oxyhydr)oxides are key scavengers of $\mathrm{P}$ in As-rich shallow submarine hydrothermal sediments, demonstrated by efficient binding of $\mathrm{P}$ when dissolved As concentrations are experimentally increased (Chi Fru et al. 2016b). It is possible that precipitated $\mathrm{P}$ is recycled into porewater 


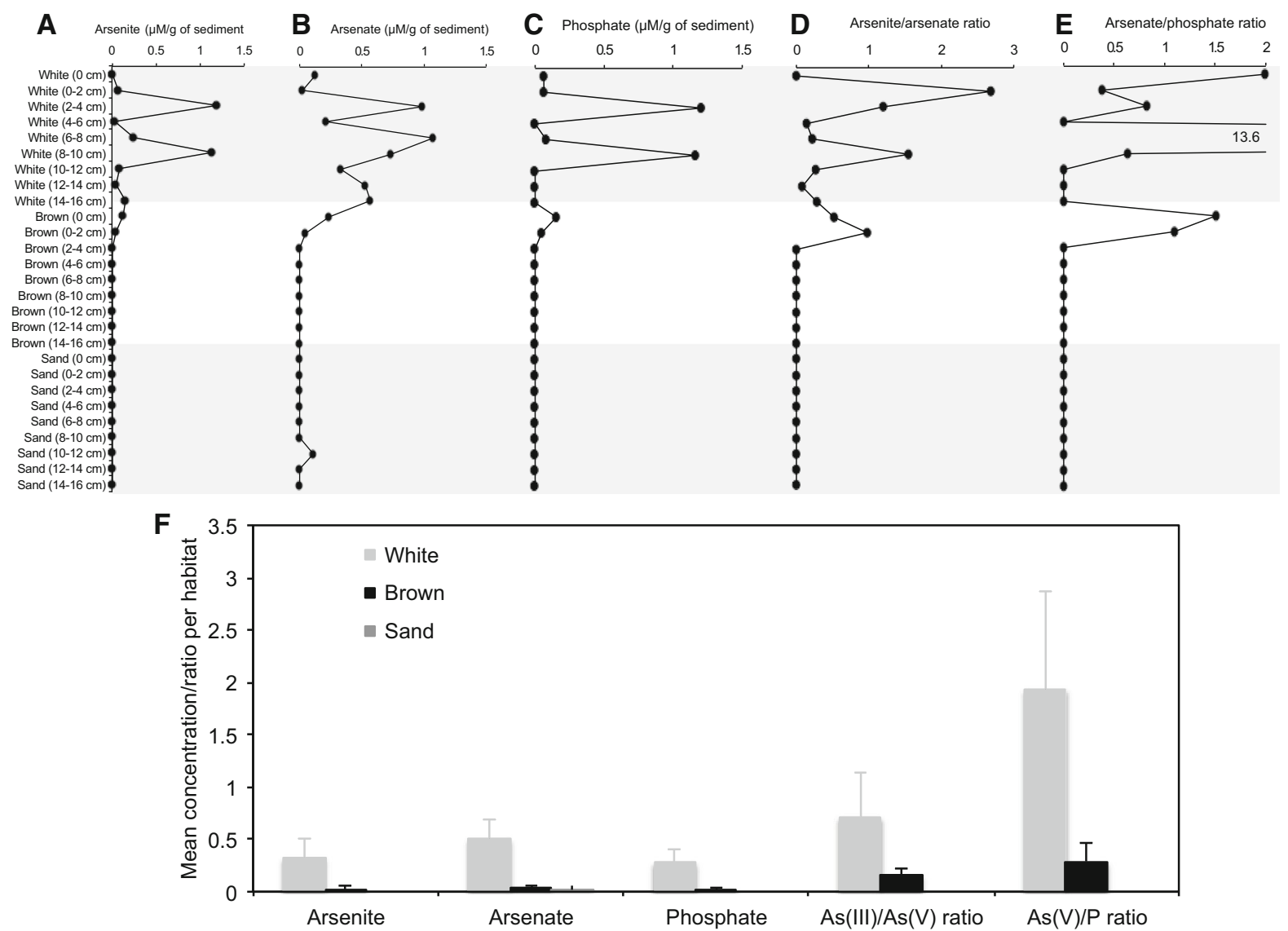

Fig. 5 Arsenate, arsenite and phosphate distribution in sediment porewater. a Arsenite. b Arsenate. c Phosphate. d Arsenite/Arsenate ratio. e Arsenate/phosphate ratio. f Mean

through the reduction of $\mathrm{Fe}(\mathrm{III})$ (oxyhydr)oxide by sulfide and the Fe-reducing bacteria. For instance, Fereducing bacteria in the lineage Geobacteraceace (Röling et al. 2014) are prevalent in the sediments together with sulfide.

As and $\mathrm{P}$ cycling gene distribution

The highly conserved function and expression of the aoxB, arrA, arsB, acr3-1 and acr3-2 genes in phylogenetically and metabolically unrelated prokaryotic lineages, is determined primarily by environmental As content. The pst gene is required for survival in geothermal environments experiencing high $\mathrm{As}(\mathrm{V})$ to phosphate ratios (e.g., Elias et al. 2012). We record similar high $\mathrm{As}(\mathrm{V})$ to phosphate ratios in the whitecapped sediments, which decline dramatically in sediments tested across the sampling transect through concentration, arsenite/arsenate and arsenate/phosphate ratios. Bars standard deviation from the mean. Concentrations are per gram of sediment

the brown-capped deposit to the sand reference (Fig. 5e). Collectively, this evidence indicates that the abundance of the aox $B, \operatorname{arr} A, \operatorname{ars} B, \operatorname{acr} 3-1, \operatorname{acr} 3-2$ and $p s t B$ genes in nature is largely dependent on environmental As concentration and less on phylogenetic affiliation.

Thus, the well-constrained Geobacteraceae arrA, acr3-1, acr3-2 and pstB gene models are used to track the distribution of these genes across the sampled transect on the basis that shifts in the content of the Geobacteraceae-specific genes should correlate with changes in sedimentary As dynamics and whole microbial community composition and abundance. The aoxB, arrA, acr3-1, acr3-2, pstB and Geobacteraceae 16S rRNA gene concentration, increased from the hydrothermal centers to the sand-capped sediments (Fig. 6), coinciding with a similar increase in whole community $16 \mathrm{~S}$ rRNA gene abundance from 
the hydrothermal centre to the sand reference (Callac et al. 2017). Moreover, metagenomic data in review elsewhere are consistent with the systematic increase in microbial community composition and functional gene abundance from the white-capped sediment to the peripheral sand-capped habitat. The metagenomic analysis also indicated that genes involved in $\mathrm{As}(\mathrm{V})$ respiration and $\mathrm{As}(\mathrm{III})$ oxidation are dramatically low, being below detection limit in a majority of samples. Similar to the qPCR data in study, As detoxification genes predominated the metagenomic library, with acr gene content being the most prevalent in the sediments.

Importantly, the metabolically versatile Geobacteraceae use a variety of mechanisms to reduce Fe(III) and $\mathrm{Mn}(\mathrm{IV})$ oxides and can also oxidize S (Röling 2014). In addition, they are capable of expressing $\operatorname{arr} A, \operatorname{ars} B, \operatorname{acr} 3-1, \operatorname{acr} 3-2$, and the pst genes, which were all targeted and quantified in this study (Giloteaux et al. 2013; N'Guessan et al. 2010). Fe oxides and $\mathrm{S}$ compounds also show strong zonation across the sampled transect (Figs. 3, 4; Table 1). This is consistent with the distribution of sediment $a o x B$ gene content, Geobacteraceae-specific As cycling arrA, arsB, acr3-1 and acr3-2 genes, together with the Geobacteraceae-specific 16S rRNA (Fig. S2) and whole microbial community $16 \mathrm{~S}$ rRNA genes used for phylogenetic reconstruction (Callac et al. 2017). $\mathrm{Mn}(\mathrm{IV})$ oxides are actively being precipitated in the different sediment types (Callac et al. 2017). Thus the Geobacteraceae arrA, arsB, acr3-1, acr3-2, pstB and Geobacteraceae 16S rRNA gene distribution, effectively maps over the mineralogical and chemical map of the three distinct sediment habitats. This distribution is relevant for testing our central hypothesis that $\mathrm{S}$ and $\mathrm{Fe}$ mineralogy are crucial for the distribution of As and $\mathrm{P}$ cycling genes in hydrothermal sediments.

Most of the genes show a general high content in the first $6 \mathrm{~cm}$ sediment depth, with the lowest values encountered in seawater (Fig. 6a). Average sediment As cycling gene content decreased in the order acr3$1>\operatorname{acr} 3-2>\operatorname{aox} B>\operatorname{ars} B>\operatorname{arr} A$. According to habitat, As cycling gene density decreased from the sand-capped sediment, through the sediment covered by the brown deposit, to the centrally located whitecapped sediment. Seawater had the lowest concentration of As-cycling gene density. A similar trend was observed for the distribution of the Geobacteraceaespecific pstB genes (Fig. 6b). A plot of
Geobacteraceae 16S rRNA gene distribution against the various As-cycling and Geobacteraceae-specific pst $B$ genes shows a correlation among all seven genes (Fig. 7). However, the ratio of the Geobacteraceaespecific 16S rRNA gene abundance to the Geobacteractereace-specific pstB density (inset Fig. 6b) is inversely related to Geobacteraceae pst $B$ gene content for each habitat (Fig. 6b). Finally, the Geobacteraceae-specific pstB and As-cycling gene content exhibit an inverse, correlation with sedimentary sulfide content (Fig. S3), implying a positive relationship with the $\mathrm{Fe}$ (III)(oxyhydr)oxides that increased in the opposite direction to sulfide (Fig. 3d, f). The several orders of magnitude lower content for all seven genes in the seawater column, relative to sediment, suggests in situ biogeochemical processes are responsible for generating the observed sediment variability. The data also imply that the metabolic processes controlled by these genes play a more important role in sediment biogeochemistry than seawater.

Temperatures in the studied systems are known to consistently decrease up the sediment profile and away from the hydrothermal centers. For example, sediment temperatures of $\sim 80$ to $100{ }^{\circ} \mathrm{C}$ at $\sim 12 \mathrm{~cm}$ depths in the vent centers typically drop rapidly upwards, reaching $\sim 24$ to $35^{\circ} \mathrm{C}$ at the seafloor (Brinkhoff et al. 1999; Sievert et al. 1999, 2000). At a distance of $4 \mathrm{~m}$ from the emission centers, temperatures fall to $\sim 21{ }^{\circ} \mathrm{C}$ at $\sim 12 \mathrm{~cm}$, with little or no upward variability (Brinkhoff et al. 1999; Sievert et al. 1999, 2000). As already mentioned above, $\mathrm{pH}$ increases from $<5.0$ to $\sim 8.0$, away from the hydrothermal loci. Therefore, it is possible that temperatures and $\mathrm{pH}$ might account for the differences seen in As and pstB gene abundance, going from the white-capped sediments in the hydrothermal center through to the peripheral habitats, located $\sim 4 \mathrm{~m}$ away. For example, microbial cell counts tend to decrease vertically upwards and increase laterally away from the centers of emission on the seafloor (Sievert et al. 1999, 2000; Giovannelli et al. 2013). However, the ratio of whole community Geobacteraceae-specific 16S rRNA gene content to Geobacteraceace pst $B$-specific gene abundance is inversely related to the Geobacteraceae pstB gene density per habitat (Fig. 6b). This important observation suggests that Geobacteraceae 16S rRNA gene abundance is decoupled from Geobacteraceae-specific community pst $B$ gene composition. That is, the pst $B$ gene content 
Fig. 6 Average arsenic and high affinity phosphate gene abundance in sediment and seawater. a Average gene abundance for the periplasmic aox $B$, ars $B$ and acr3-1 and acr3-2 and arrA genes. $\mathbf{b}$ pst $B$ gene abundance specific for the Geobacteraceae
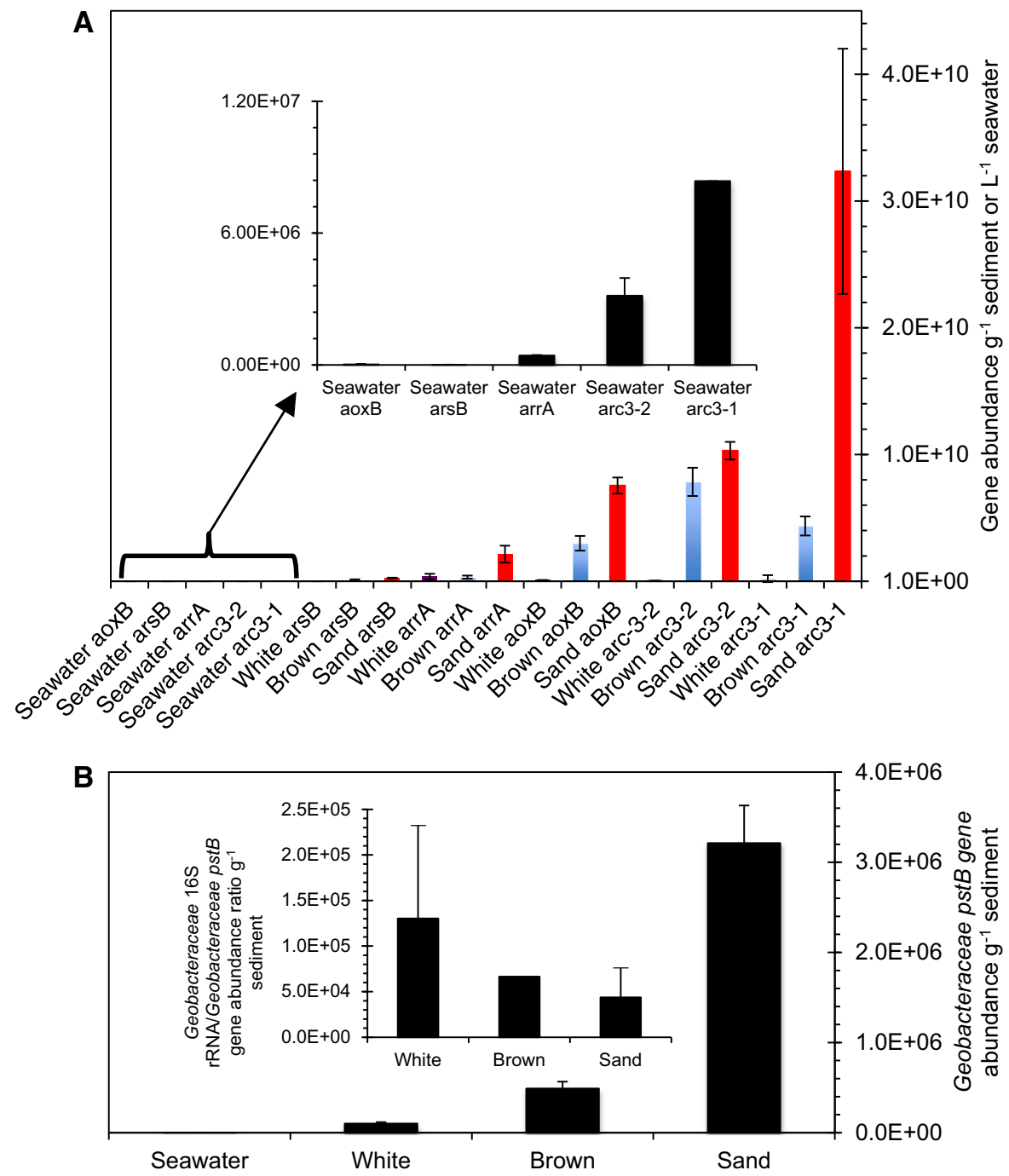

does not scale positively with the Geobacteraceae cell density present in each setting. This would be expected if genetic abundance simply reflects increasing cell population density controlled by favourable habitat conditions away from the extreme hydrothermal centers.

The latter assumption is based on the fact that $16 \mathrm{~S}$ rRNA genes are inherited vertically and because increasing favorable environmental conditions correlate positively with environmental 16S rRNA gene content (Lee et al. 2009). Consequently, specific 16S rRNA gene abundance for targeted phylogenetic groups of microorganisms in an environmental sample, scale linearly with cell count after taking into account the copy number of $16 \mathrm{~S}$ rRNA genes (Lee et al. 2009). The Geobacteraceae family-specific pstB gene data was therefore normalized to Geobacteraceae family-specific 16S rRNA gene abundance, since the latter is expected to scale with local total Geobacteraceae cell density. On the other hand, the Geobacteraceae-specific pstB gene is expected to scale with the subset of Geobacteraceae community members containing high affinity phosphate uptake specific genes in their genome. The data suggest that the increasing sediment Geobacteraceae-specific pstB gene abundance, known to respond to $\mathrm{P}$ limitation (N'Guessan et al. 2010), was not related to a general increase in Geobacteraceae population density away from the hydrothermal loci. Therefore, the data imply that increasing habitable conditions related to 


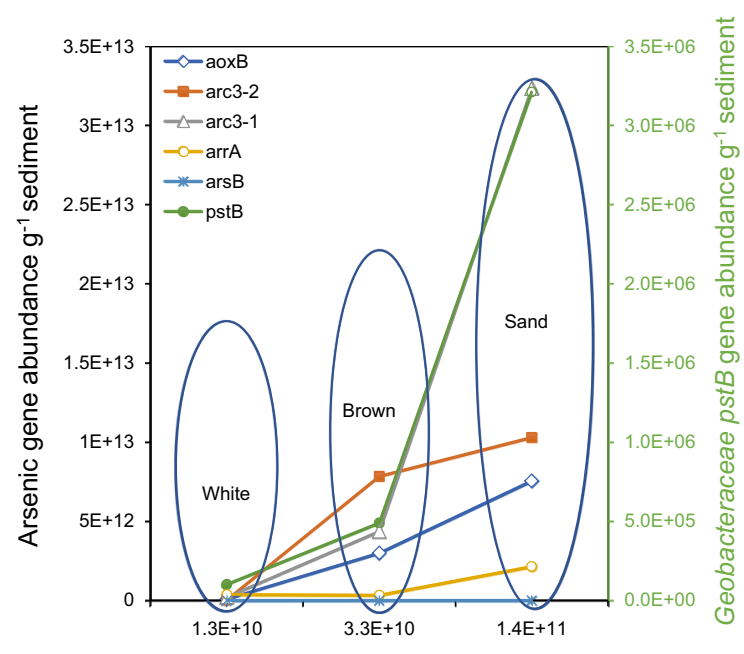

Geobacter $16 \mathrm{~S}$ rRNA gene abundance $\mathrm{g}^{-1}$ sediment

Fig. 7 Geobacteraceae 16S rRNA gene abundance against As and high affinity phosphate uptake genes. Linear fit with $\mathrm{R}^{2}$ values of $0.98403,0.96795,0.91712,0.84513,0.84194$ and 0.73033 for $\operatorname{aoxB}, \operatorname{ars} B, \operatorname{acr} 3-2, \operatorname{acr} 3-1$, pstB and $\operatorname{arr} A$, respectively

temperature and $\mathrm{pH}$, with distance away from the hydrothermal vents, are not the main factors underlining the enrichment of pstB genes along the studied transect.

As expected, the paired variables of Geobacteraceae-specific 16S rRNA gene content and the individual genes, validate the fact that the Geobacteraceae-specific $16 \mathrm{~S}$ rRNA genes, together with the measured genes, follow the established trend of total sediment gene content increasing from the hydrothermal center to the reference sand (Callac et al. 2017). The data should therefore not be interpreted to mean that the Geobacteraceae are the sole contributors of the genes analysed in the sediments. For example, the $\mathrm{R}^{2}$ value between Geobacteraceae-specific 16S rRNA gene content and the pst $B$ gene is 0.84194 . This $\mathrm{R}^{2}$ value equates to a $\sim 84 \%$ positive variation between the two variables, suggesting that $\sim 16 \%$ of the detected Geobacteraceae-related lineages along the sampled transect might not necessarily carry the $p s t B$ gene. This correlation could be attributed to the strong variability of phosphate abundance in the different habitats. Similarly, the $>90 \%$ positive variation between the Geobacteraceae-specific 16S rRNA gene content and the arsenic detoxification genes, aoxB, $\operatorname{ars} B$ and $\operatorname{acr} 3-2$, suggests that the sediments enrich a Geobacteraceae assemblage with strong resistance against As toxicity in all three habitats. Consistent with this view, it has been observed that the Geobacteraceae respond to increasing As content via the upregulation of As detoxification genes in the acr3 gene family (N'Guessan et al. 2010). Importantly, the acr3 gene content, which is the most abundant As detoxification gene in the sediments, covaries positively with the Geobacteraceae family 16S rRNA gene abundance (Fig. 7).

\section{Control on As and P cycling gene enrichment}

The low As resistance gene content in the seawater column is several orders of magnitude lower than sediment concentrations (Fig. 6a). This suggests that As stress in seawater is negligible relative to the sediments. It also indicates that the overlying seawater microbial communities may be more vulnerable to sudden As perturbation than those inhabiting the sediments. Moreover, As precipitation by Mn oxides, $\mathrm{Fe}(\mathrm{III})$ (oxyhydr)oxides and particularly As sulfides (Cullen and Reimer 1989; Smedley and Kinniburgh 2002; Maity et al. 2005; Henke et al. 2009; Kilias et al. 2013; Godelitsas et al. 2015), are suggested as effective processes preventing dramatic contamination of seawater by hydrothermal As-rich fluids. This, in addition to dilution of the hydrothermal fluids by seawater, likely accounts for the lower seawater $\mathrm{As}(\mathrm{V})$ and As(III) respiratory reductases and oxidases content in comparison to the sediments. The extraordinary predominance of As(III) extrusion genes in the sediments (Fig. 6a), further hint that respiratory $\mathrm{As}(\mathrm{V})$ and $\mathrm{As}(\mathrm{III})$ energy conservation are likely overwhelmed by As detoxification (resistance). As detoxification is suggested to be most likely intense in the sand sediment, where reactive $\mathrm{S} / \mathrm{Fe}$ ratio minima coincide with As resistance gene maxima. The low high affinity phosphate uptake gene concentration in seawater, despite the fact that dissolved $\mathrm{P}$ content is equally limiting, is likely related to the fact that the Geobacteraceae thrive well when oxygen is absent. As demonstrated by our data, seawater was well ventilated.

Several quantitative studies have shown that microbial adaptation to phosphate availability depends on lineage, population size, nutrient requirements and rates of metabolism (e.g., Jansson 1993; Van Mooy et al. 2006, 2009; Karl 2014; Lin et al. 2016). High affinity phosphate uptake predominates when $\mathrm{As}(\mathrm{V}) /$ 

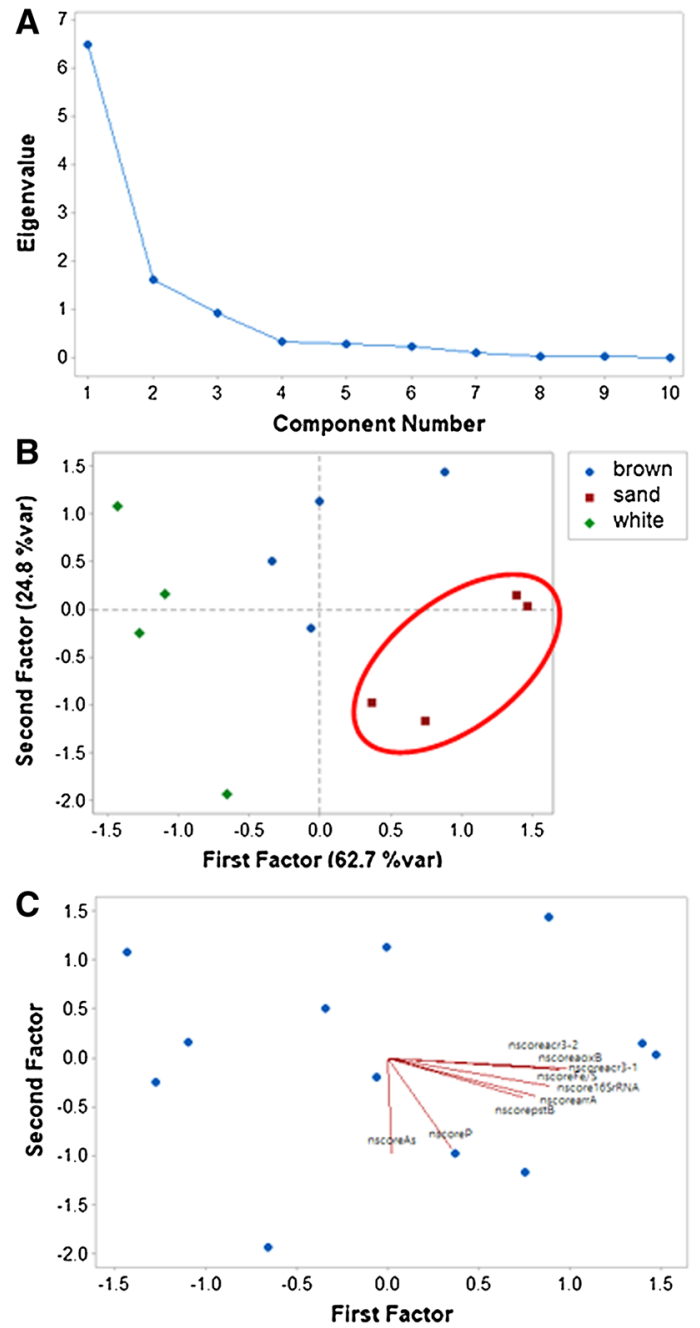

Fig. 8 Principal component analysis (PCA). Plots are for selected parameters, As respiration, As resistance and high affinity phosphate uptake genes, total sediment $\mathrm{P}$ and As and reactive $\mathrm{Fe}$ to $\mathrm{S}$ ratios. a Screen plot showing a maximum of

Phosphate ratios rise above a certain threshold (Elias et al. 2012) and/or when P levels are extremely low, regardless of whether $\mathrm{As}(\mathrm{V})$ is present or absent (Thiel 1988; Takahashi et al. 1990; Jansson 1993; Dyhrman and Haley 2011; Guo et al. 2011; Karl 2014; Lin et al. 2016). The significant decrease in As(V)/phosphate ratio from the white to the sand reference (Fig. 5e, f), suggests that the low $\mathrm{P}$ content encountered in the brown-/sand-capped sediments drives the enrichment of high affinity $\mathrm{P}$ uptake genes away from the white capped-sediment. If the $\mathrm{As}(\mathrm{V}) / \mathrm{phosphate}$ ratio were important, then one would naturally expect high affinity P-uptake gene abundance to peak in the

D

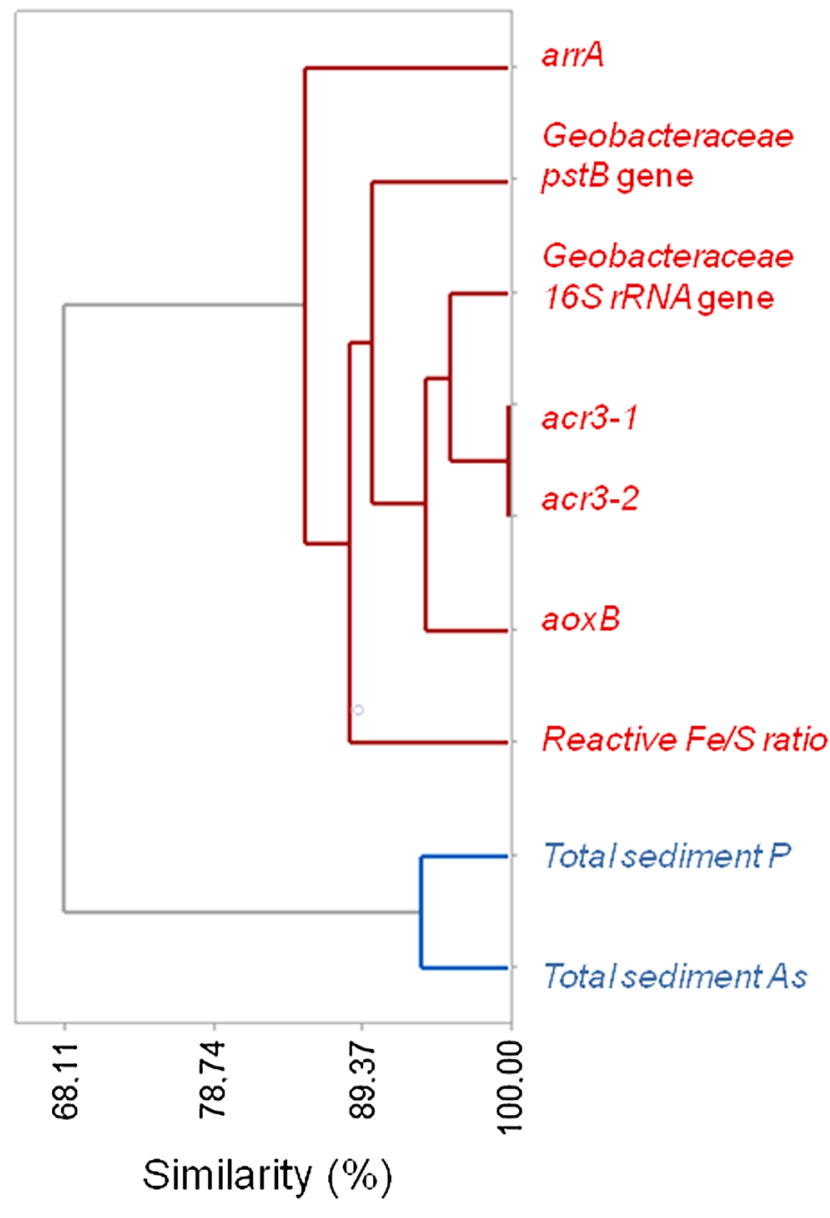

three-factor analysis possible for the dataset. b Three-factor PCA analysis of the correlation matrix plotted against habitat (see Table S3 for calculated variables). c Sediment biplot. d Complete linkage-correlation distance similarity dendrogram

white-capped sediments that contain As(V)/phosphate ratios that are $>1$ and several orders of magnitude above those in the brown and sand-capped sediments. The generally lower microbial population density in the white-capped sediments also implies less competition for nutrients, including $\mathrm{P}$, compared to the brown and sand-capped sediments that are progressively enriched in microbial abundance (Callac et al. 2017). Therefore, the dissolved $P$ content coupled to microbial abundance, drives the enrichment of high affinity $\mathrm{P}$ uptake genes in the sediments over the As(V)/phosphate ratio. 
Results of factor analysis (Table S3) provide evidence that the changing $\mathrm{Fe} / \mathrm{S}$ ratio is closely related to the genomic presence of the studied As- and Pgenes. It is noted that the ars $B$ gene was not considered because of its low abundance in all types of sediment (Fig. 6a). Specifically, a two-factor solution accounting for $87.5 \%$ of the total variance is identified based on the scree plot criterion (Fig. 8a-c). The changing reactive $\mathrm{Fe} / \mathrm{S}$ ratio is grouped with the Geobacteraceae pstB gene, the predominant As(III) efflux pump acr3-1 and acr3-2 genes, the respiratory $\mathrm{As}(\mathrm{V})$ reductases (arrA) and As(III) oxidases (aoxB) in Factor 1 (62.7\% of total variance). Total sediment $\mathrm{P}$ and As are grouped independently in Factor 2 (24.8\% of total variance) (Table S3). There is a clear separation of the sand-capped habitat from the white-/brown-capped sediments (Fig. 8b). It should be emphasized that the robustness of factor analysis is limited by the dimensionality of the data determined by the availability of a sufficient number of samples for the number of variables (Reimann et al. 2008). However, the grouping of variables is further supported by the cluster analysis results which are presented graphically in a dendrogram (Fig. 8d). The similarity axis represents the degree of association between the variables, the greater the value the more significant the association.
There is a corresponding high similarity $(>85.35 \%)$ between reactive $\mathrm{Fe} / \mathrm{S}$ ratios and the studied genes, while Total sediment $\mathrm{P}$ and As form a separate cluster of high similarity level (>93.75\%) (Fig. 8d). Studies tracking the expression levels of the specific Geobacteraceae pst $B$ genes by rtqPCR relative to $\mathrm{P}$ bioavailability, suggest the PstB proteins are switched on under similar P-limiting conditions, as reported in this study (N'Guessan et al. 2010). Moreover, in situ respiratory arrA genes were concomitantly unregulated, together with the acr3 As resistance genes, in the Geobacteraceae, following increase in dissolved As content (N'Guessan et al. 2010; Giloteaux et al. 2013).

\section{Conclusions}

This study, focused on the coast of Milos Island, Greece, presents a comprehensive biogeochemical model for the fate of As and P in As-rich shallow submarine hydrothermal ecosystems, on the coast of Milos Island, Greece, demonstrating that:

- Quantitative regulation of dissolved porewater As and $\mathrm{P}$ concentration by sulfide and $\mathrm{Fe}(\mathrm{III})$ (oxyhydr)oxide minerals during sediment-seawater

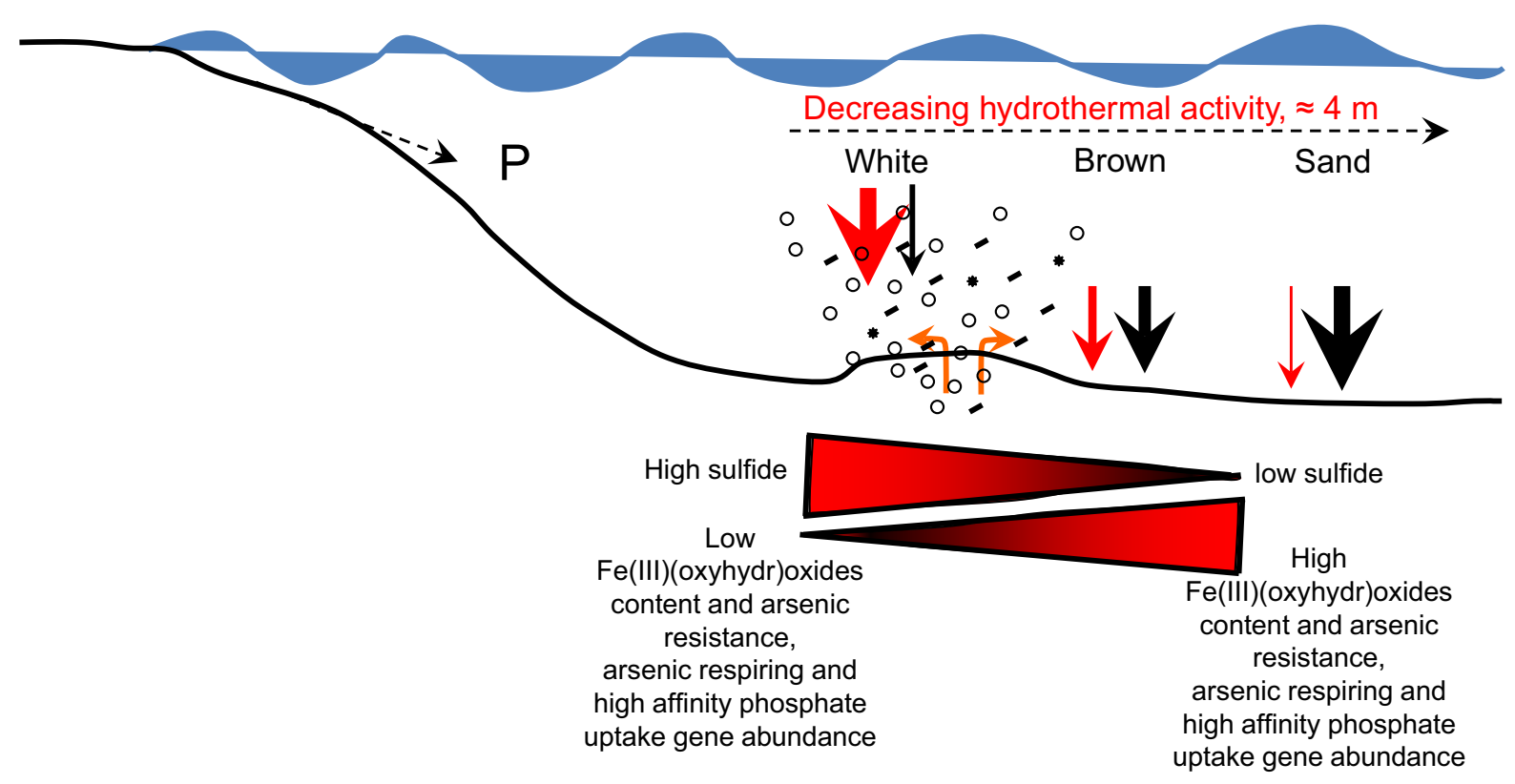

Fig. 9 Conceptual model for As and $\mathrm{P}$ cycling along the sampled transect. The size of the red and black arrows are proportional to the quantity of As sulfides and
$\mathrm{Fe}(\mathrm{III})$ (oxyhydr)oxides precipitated and stored in sediments. Open circles represent hydrothermal gas bubbles 
interaction, produce nutrient-deficient porewaters containing $<2.0 \mathrm{ppb}$ phosphorus.

- Reactive $S$ to reactive Fe ratios may be critical in determining the distribution of genes required for As resistance, As respiratory and high affinity phosphate uptake in As-rich shallow submarine hydrothermal sediments (Fig. 9).

- The sediments and seawater contain disproportionately lower As-respiring gene content relative to As resistance genes, suggesting that As detoxification is crucial for survival over As metabolism.

- The predominance of As detoxification genes, especially acr3 genes encoding the environmentally widespread Acr3 As(III) extrusion protein, implies the sediment community harbors a tremendous capacity for rapid response to sudden As perturbation.

- The distribution of high affinity phosphate uptake genes is suggested to be dependent on sediment pore phosphate concentration, which in turn is controlled by $\mathrm{Fe}(\mathrm{III})$ (oxyhydr)oxides content and scavenging.

Acknowledgements This study was funded by a European Research Council (ERC) Seventh Framework Programme Grant No. 336092. Katerina Gkika, Christoffer Hemmingsson and Eva Zygouri are acknowledged for fieldwork assistance. We thank Volker Brüchert for help with the sulfide extraction experiments. NP thanks the Seventh Framework Program of the European Union Marie Skłodowska-Curie Intra-European Fellowships (BioCTrack 330064) for their support.

Open Access This article is distributed under the terms of the Creative Commons Attribution 4.0 International License (http:// creativecommons.org/licenses/by/4.0/), which permits unrestricted use, distribution, and reproduction in any medium, provided you give appropriate credit to the original author(s) and the source, provide a link to the Creative Commons license, and indicate if changes were made.

\section{References}

Bayraktarov E, Price RE, Ferdelman TG, Finster K (2013) The $\mathrm{pH}$ and $\mathrm{pCO}_{2}$ dependence of sulfate reduction in shallowsea hydrothermal $\mathrm{CO}_{2}$-venting sediments (Milos Island, Greece). Front Microbiol. https://doi.org/10.3389/fmicb. 2013.00111

Breuer C, Pichler T (2013) Arsenic in marine hydrothermal fluids. Chem Geol 348:2-14
Brinkhoff T, Sievert S, Kuever J, Muyzer G (1999) Distribution and diversity of sulfur-oxidizing Thiomicrospira spp. At a shallow-water hydrothermal vent in the Aegean Sea (Milos, Greece). Appl Environ Microbiol 65(9):3843-3849

Brock J, Schulz-Vogt HN (2011) Sulfide induces phosphate release from polyphosphate in cultures of a marine Beggiatoa strain. ISME J 5(3):497-506

Cai L, Liu G, Rensing C, Wang G (2009) Genes involved in arsenic transformation and the resistance associated with different levels of arsenic-contaminated soils. BMC Microbiol. https://doi.org/10.1186/1471-2180-9-4

Callac N, Rouxel O, Lesongeur F, Liorzou C, Bollinger C, Pignet P, Chéron S, Fouquet Y, Rommevaux-Jestin C, Godfroy A (2015) Biogeochemical insights into microbemineral-fluid interactions in hydrothermal chimneys using enrichment culture. Extremophiles 19(3):597-617

Callac N, Posth NR, Rattray JE, Yamoah KA, Wiech A, Ivarsson M, Hemmingsson C, Kilias SP, Argyraki A, Broman C, Skogby H, Smittenberg RH, Chi Fru E (2017) Modes of carbon fixation in an arsenic and $\mathrm{CO}$ 2-rich shallow hydrothermal ecosystem. Sci Rep. https://doi.org/10.1038/ s41598-017-13910-2

Canfield DE (1998) A new model for Proterozoic ocean chemistry. Nature 396:450-453

Chen S-C, Sun GX, Rosen BP, Zhang S-Y, Deng Y, Zhu B-K, Rensing C, Zhu Y-G (2017) Recurrent horizontal transfer of arsenite methyltransferase genes facilitated adaptation of life to arsenic. Sci Rep 7:7741. https://doi.org/10.1038/ s41598-017-08313-2

Chi Fru E, Ivarsson M, Kilias SP, Bengtson S, Belivanova V, Marone F, Fortin D, Broman C, Stampanoni M (2013) Fossilized iron bacteria reveal a pathway to the biological origin of banded iron formation. Nat Commun. https://doi. org/10.1038/ncomms 3050

Chi Fru E, Arvestål E, Callac N, El Albani A, Kilias S, Argyraki A, Jakobsson M (2015a) Arsenic stress after the Proterozoic glaciations. Sci Rep 5:17789. https://doi.org/10.1038/ srep 17789

Chi Fru E, Ivarsson M, Kilias SP, Frings PJ, Hemmingsson C, Broman C, Bengtson S, Chatzitheodoridis E (2015b) Biogenicity of an early quaternaru iron formation, Milos Island, Greece. Geobiology 13(3):225-244

Chi Fru E, Rodriguez NP, Partin CA, Lalonde SV, Andersson P, Weiss DJ, El Albani A, Rodushkin I, Konhauser KO (2016a) Cu isotopes in marine black shales record the great oxidation event. Proc Natl Acad Sci USA 113(18):4941-4946

Chi Fru E, Hemmingsson C, Holm M, Iñiguez E (2016b) Arsenic-induced phosphate limitation under experimental early proterozoic oceanic conditions. Earth Plan Sci Lett 334:52-63

Chi Fru E, Hemmingsson C, Callac N, Perez N, Panova EG, Broman C, El Albani A (2016c) Atmospheric weathering of Scandinavian alum shales and the fractionation of $\mathrm{C}, \mathrm{N}$ and S isotopes. Appl Geochem 7:94-108

Chi Fru E, Kilias S, Ivarsson M, Rattray JE, Gkika K, McDonald I, He Q, Broman C (2018) Sedimentary mechanisms of a modern banded iron formation on Milos Island, Greece. Solid Earth 9:1-26. https://doi.org/10.5194/se-9-1-2018

Cline JD (1969) Spectrophotometric determination of hydrogen sulfide in natural waters. Limnol Oceanogr 14(3):454-458 
Cullen WR, Reimer KJ (1989) Arsenic speciation in the environment. Chem Rev 89(4):713-764

Dando PR, Hughes JA, Leahy YS, Niven J, Taylor LJ, Smith C (1995) Gas venting rates from submarine hydrothermal areas around the Island of Milos, Hellenic Volcanic Arc. Cont Shelf Res 15(8):913-929

Dekov VM, Bindi L, Burgaud G, Petersen S, Asael D, Rédou V, Fouquet Y, Pracejus B (2013) Inorganic and biogenic Assulfide precipitation at seafloor hydrothermal fields. Mar Geol 342:28-38

Dhar RK, Zheng Y, Rubenstone J, van Geen A (2004) A rapid colorimetric method for measuring arsenic concentrations in groundwater. Anal Chim Acta 526(2):203-209

Dixit S, Hering JG (2003) Comparison of $\operatorname{arsenic}(V)$ and arsenic(III) sorption onto iron oxide minerals: implications for arsenic mobility. Environ Sci Technol 37(18):4182-4189

Dyhrman ST, Haley ST (2011) Arsenate resistance in the unicellular marine diazotroph Crocosphaera watsonii. Frontiers Microbiol. https://doi.org/10.3389/fmicb.2011.00214

Dziubinska-Maciaszczyk E, Migocka M, Wysocki R (2011) Acr3p is a plasma membrane antiporter that catalyzes $\mathrm{As}(\mathrm{III}) / \mathrm{H}+$ and $\mathrm{Sb}(\mathrm{III}) / \mathrm{H}^{+}$exchange in Saccharomyces cerevisiae. Biochim Biophy Acta 1808(7):1855-1859

Edmonds H, German C (2004) Particle geochemistry in the Rainbow hydrothermal plume, Mid-Atlantic Ridge. Geochim Cosmochim Acta 68(4):759-772

Elias M, Wellner A, Goldin-Azulay K, Chabriere E, Vorholt JA, Erb TJ, Tawfik DS (2012) The molecular basis of phosphate discrimination in arsenate-rich environments. Nature 491(7422):134-137

Feely RA, Baker ET, Marumo K, Urabe T, Ishibashi J, Gendron J, Lebon GT, Okamura K (1996) Hydrothermal plume particles and dissolved phosphate over the superfastspreading southern East Pacific Rise. Geochim Cosmo Acta 60(13):2297-2323

Feely RA, Trefry JH, Lebon GT, Herman CR (1998) The relationship between $\mathrm{P} / \mathrm{fe}$ and $\mathrm{V} / \mathrm{Fe}$ in hydrothermal precipitates and dissolved phosphate in seawater. Geophy Res Lett 25(13):1153-1156

Fu H-L, Meng Y, Ordóñez E, Villadangos AF, Bhattacharjee H, Gil JA, Mateos LM, Rosen BP (2009) Properties of arsenite efflux permeases (Acr3) from Alkaliphilus metalliredigens and Corynebacterium glutamicum. J Biol Chem 284(30):19887-19895

Gihring TM, Bond PL, Peters SC, Banfield JF (2003) Arsenic resistance in the archaeon "Ferroplasma acidarmanus: new insights into the structure and evolution of the ars genes. Extremophiles 7(2):123-130

Gilhooly WP, Fike DA, Druschel GK, Kafantaris FC, Price RE, Amend JP (2014) Sulfur and oxygen isotope insights into sulfur cycling in shallow-sea hydrothermal vents, Milos, Greece. Geochem Trans. https://doi.org/10.1186/s12932014-0012-y

Giloteaux L, Holmes DE, Williams KH, Wrighton KC, Wilkins MJ, Montgomery AP, Smith JA, Orellana R, Thompson CA, Roper TJ, Long PE, Lovley DR (2013) Characterization and transcription of arsenic respiration and resistance genes during in situ uranium bioremediation. ISME J 7(2):370-383

Giovannelli D, d'Errico G, Manini E, Yakimove M, Vetriani C (2013) Diversity and phylogenetic analyses of bacteria from a shallow-water hydrothermal vent in Milos Island (Greece). Frontiers Microbiol. https://doi.org/10.3389/ fmicb.2013.00184

Godelitsas A, Price RE, Pichler T, Amend J, Gamaletsos P, Göttlicher J (2015) Amorphous As-sulfides precipitates from the shallow-water hydrothermal vents off Milos Island (Greece). Mar Chem 177(Part 5):687-696

Guo P, Gong Y, Wang C, Liu X, Liu J (2011) Arsenic speciation and effect of arsenate inhibition in a microcystis aeroginosa culture medium under different phosphate regimes. Environ Toxicol Chem 30(8):1754-1759

Harrington CF, Brima EI, Jenkins RO (2008) Biotransformation of arsenobetaine by microorganisms from the human gastrointestinal tract. Chem Speciat Bioavailab 20(3):173-180

Hawkes JA, Connelly DP, Rijkenberg JA, Achterberg EP (2014) The importance of shallow hydrothermal island arc systems in ocean biogeochemistry. Geophy Res Lett 41(3):942-947

Hemmingsson C, Pitcairn I, Chi Fru E (2018) Evaluation of phosphate-uptake mechanisms by Fe(III) (oxyhydr)oxides in early proterozoic oceanic conditions. Environ Chem In Press. https://doi.org/10.1071/EN17124

Henke KR (2009) Arsenic in the natural environment. In: Henke KR (ed) Arsenic environmental chemistry: health threats and waste water treatment. Wiley, West Sussex, pp 69-235

Hoffmann T, Warmbold B, Smits SHJ, Tschapek B, Ronzheimer S, Bashir A, Chen C, Rolbetzki A, Pittelkow M, Jebbar M, Seubert A, Schmitt L, Bremer E (2018) Arsenobetaine: an ecophysiologically important organoarsenical confers cytoprotection against osmotic stress and growth temperature extremes. Environ Microbiol 20(1):305-323

Jackson CR, Dugas SL (2003) Phylogenetic analysis of bacterial and archaeal ars $C$ gene sequences suggests an ancient, common origin for arsenate reductase. BMC Evol Biol. https://doi.org/10.1186/1471-2148-3-18

Jansson M (1993) Uptake, exchange, and excretion of orthophosphate in phosphate-starved Scenedesmus quadricauda and Pseudomonas K7. Limnol Oceanogr 38(6):1162-1178

Jiang Z, Li P, Jiang D, Wu G, Dong H, Wang Y, Li B, Guo Q (2014) Diversity and abundance of the arsenite oxidase gene aioA in geothermal areas of Tengchhong, Yunnan, China. Extremophiles 18(1):161-170

Johnson DL (1971) Simultaneous determination of arsenate and phosphate in natural waters. Environ Sci Technol 5(5):411-414

Johnson DL, Pilson MEQ (1972) Spectrophotometric determination of arsenite, arsenate, and phosphate in natural waters. Ana Chim Acta 58(2):289-299

Kallmeyer J, Ferdelman TG, Weber A, Fossing H, Jørgensen BB (2004) A cold chromium distillation procedure for radiolabeled sulfide applied to sulfate reduction measurements. Limnol Oceanogr 2(6):171-180

Karl DM (2014) Microbially mediated transformations of phosphorus in the sea: new views of an old cycle. Annu Rev Sci 6:279-337

Kilias SP, Nomikou P, Papanikolaou D, Polymenakou PN, Godelitsas A, Argyraki A, Carey S, Gamaletos P, Mertzimekis TJ, Stathopoulou E, Goettlicher J, Steininger R, Betzelou S, Livanos I, Christakis C, Bell KX, Scoullos M (2013) New insights into hydrothermal vent processes in 
the unique shallow-submarine arc-volcano, Kolumbo (Santorini), Greece. Sci Rep. https://doi.org/10.1038/ srep02421

Kumari N, Jagadevan S (2016) Genetic identification of arsenate reductase and arsenite oxidase in redox transformations carried out by arsenic metabolising prokaryotes-a comprehensive review. Chemosphere 163:400-412

Lafferty BJ, Ginder-Vogel M, Sparks DL (2011) Arsenite oxidation by a poorly-crystalline manganese oxide. 3. arsenic and manganese desorption. Environ Sci Technol 45(21):9218-9223

Lee ZM-P, Bussema C, Schmidt TM (2009) rrnDB: documenting the number of rRNA and tRNA genes in bacteria and archaea. Nucleic acids Res 37(1):D489-D493

Lengke MF, Sanpawitchakit C, Tempel RN (2009) The oxidation and dissolution of arsenic-bearing sulfides. Can Min 47(3):593-613

Lin S, Litaker RW, Sunda WG (2016) phosphorus physiological ecology and molecular mechanisms in marine phytoplankton. J Phycol 5(1):10-35

Maher W, Butler E (1988) Arsenic in the marine environment. Appl Organomet Chem 2(3):191-214

Maity S, Chakravarty S, Bhattacharjee S, Roy BC (2005) A study on arsenic adsorption on polymetallic sea nodule in aqueous medium. Wat Res 39(12):2579-2590

Malasarn D, Saltikov CW, Campbell KM, Santini JM, Herin JG, Newmann DK (2004) arrA is a reliable marker for As(V) respiration. Science 306(5695):455

Mukhopadhyay R, Rosen BP, Phung LT, Silver S (2002) Microbial arsenic from geocycles to genes and enzymes. FEMS Microbiol Rev 26(3):311-325

N'Guessan AL, Giloteaux L, Elifantz H, Nevin KP, Mouser PJ, Methé B, Woodard TL, Manley K, William KH, Wilkin MJ, Larsen JT, Long PE, Derek RL (2010) Molecular analysis of phosphate limitation in Geobacteraceae during the bioremediation of a uranium-contaminated aquifer. ISME J 4:253-266

Newman DK, Ahmann D, Morel FMM (2009) A brief review of microbial arsenate respiration. Geomicrobiol J 15(4):255268

O'Day PA (2006) Chemistry and mineralogy of arsenic. Elements 2(2):77-83

O'Day PA, Vlassopoulos D, Root R, Rivera N (2004) The influence of sulfur and iron on dissolved arsenic concentrations in the shallow subsurface under changing redox conditions. Proc Natl Acad Sci USA 101(38):13703-13708

Oremland RS, Stolz JF (2003) The ecology of arsenic. Science 300(5621):39-944

Ouvrard S, Simonnot M-O, de Donato P, Sardin M (2002) Diffusion-controlled adsorption of arsenate on a natural manganese oxide. Ind Eng Chem Res 41(24):6194-6199

Páez-Espino D, Tamames J, de Lorenzo V, Cánovas D (2009) Microbial responses to environmental arsenic. Biometals 22(1):117-130

Poulton S, Canfield DE (2005) Development of a sequential extraction procedure for iron: Implications for iron partitioning in continentally-derived particulates. Chem Geol 214(3-4):209-221

Poulton SW, Canfield DE (2006) Co-diagenesis of iron and phosphorus in hydrothermal sediments from the southern East Pacific Rise: implications for the evaluation of paleoseawater phosphate concentrations. Geochim Cosmochim Acta 70(23):5883-5898

Poulton SW, Canfield DE (2011) Ferruginous conditions: a dominant feature of the ocean through Earth's history. Elements 7(2):107-112

Price RE, Lesniewski R, Nitzsche KS, Meyerdierks A, Saltikov C, Pichler T, Amend JP (2013a) Archaeal and bacterial diversity in an arsenic-rich shallow-sea hydrothermal system undergoing phase separation. Front Microbiol. https:// doi.org/10.3389/fmicb.2013.00158

Price RE, Savov I, Planer-Friedrich B, Bühring SI, Amend J, Pichler T (2013b) Processes influencing extreme As enrichment in shallow-sea hydrothermal fluids of Milos Island, Greece. Chem Geol 348:15-26

Qin J, Lehr CR, Yuan C, Le XC, McDermott TR, Rosen BP (2009) Biotransformation of arsenic by a yellowstone thermoacidophilic eukaryotic alga. Proc Natl Acad Sci USA 106(13):5213-5217

Quéméneur M, Salmeron-Heinrich A, Muller D, Liéremont D, Jauzein M, Bertin PN, Garrido F, Joulian C (2008) Diversity surveys and evolutionary relations of $a \circ x B$ genes in aerobic arsenite-oxidizing bacteria. Appl Environ Microbiol 74(14):4567-4573

Rascovan N, Maldonado J, Vazquez M, Farías ME (2016) Metagenomics study of red biofilms from Diamante Lake reveals ancient arsenic bioenergetics in haloarchaea. ISME J 10(2):299-309

Reimann C, Filzmoser P, Garrett R, Dutter R (2008) Statistical data analysis explained: applied environmental statistics with R. Wiley-Blackwell, Chichester

Reinhard CT, Planavsky NJ, Gill BC, Ozaki K, Robbins LJ, Lyons TW, Fischer WW, Wang C, Cole DB, Konhauser KO (2017) Evolution of the global phosphorus cycle. Nature 541:386-389

Röling WFM (2014) In: Rosenberg, S. et al (ed) The family Geobacteraceae. Springer, Berlin, pp. 159-172

Rosen BP (2002) Biochemistry of arsenic detoxification. FEBS Lett 529(1):86-92

Rosen BP, Ajees AA, McDermott TR (2011) Life and death with arsenic. BioEssays 33(5):350-357

Ruiz-Chancho MJ, Pichler T, Price RE (2013) Arsenic occurrence and speciation in Cyclop neritea, a gastropod inhabiting the arsenic-rich marine shallow-water hydrothermal system off Milos Island, Greece. Chem Geol 348:56-64

Saltikov CW, Newman DK (2003) Genetic identification of a respiratory arsenate reductase. Proc Natl Acad Sci USA 100(19):10983-10988

Sánchez-Riego AM, López-Maury L, Florencio FJ (2014) Genomic responses to arsenic in the cyanobacterium Synechocystis sp. PCC 6803. PLoS ONE. https://doi.org/ 10.1371/journal.pone.0096826

Santosa SJ, Wada S, Mokudai H, Tanaka S (1997) The contrasting behaviour of arsenic and germanium species in seawater. Appl Org Chem 11(5):403-414

Schaller T, Morford J, Emerson S, Feely RA (2000) Oxyanions in metalliferous sediments: tracers for paleoseawater metal concentrations? Geochim Cosmo Acta 64(13):2243-2254

Sievert SM, Brinkhoff T, Muyzer G, Ziebis W, Kuever J (1999) Spatial heterogeneity of bacterial population along an environmental gradient in a shallow sumarine 
hydrothermal vent area near Milos island (Greece). Appl Environ Microbiol 65(9):3834-3842

Sievert SM, Ziebis W, Kuever J, Sahm K (2000) Relative abundance of archaea and bacteria along a thermal gradient of a shallow-water hydrothermal vent quantified by rRNA slotblot hybridization. Microbiology 146(Pt 6):1287-1293

Silver S, Phung LT (2005) Genes and enzymes involved in bacterial oxidation and reduction of inorganic arsenic. Appl Environ Microbiol 71(2):599-608

Slyemi D, Bonnefoy V (2012a) How prokaryotes deal with arsenic. Environ Microbiol Rep 4:571-586

Slyemi D, Bonnefoy V (2012b) How prokaryotes deal with arsenic. Environ Microbiol Rep 4(5):571-586

Smedley PL, Kinniburgh DG (2002) A review of the source, behaviour and distribution of arsenic in natural waters. Appl Geochem 17(5):517-568

Song B, Chyun E, Jaffé PR, Ward BB (2009) Molecular methods to detect and monitor dissimilatory arsenate-respiring bacteria (DARB) in sediments. FEMS Microbiol Ecol 68(1):108-117

Stauder S, Raue B, Sacher F (2005) Thioarsenics in sulfidic waters. Environ Sci Technol 39(16):5933-5939

Stookey LL (1970) Ferrozine-a new spectrophotometric reagent for iron. Analy Chem 42(7):779-781

Takahashi A, Kawakami H, Bada A, Okonogi Y, Matsuto S (1990) Effects of phosphate on arsenate inhibition in a marine cyanobacterium Phormidium sp. Appl Organometallic Chem 4(3):269-279

Takamatsu T, Kawashima M, Koyama M (1985) The role of $\mathrm{Mn}^{2+}$-rich hydrous manganese oxide in the accumulation of arsenic in lake sediments. Wat Res 19(8):1029-1032

Tawfik DS, Viola RE (2011) Arsenate replacing phosphate: alternative life chemistries and ion promiscuity. Biochemistry 50(7):1128-1134

Thiel T (1988) Phosphate transport and arsenate resistance in the cyanobacterium Anabaeba variabilis. J Bacteriol 170(3): $1143-1147$

Tian X, Luo K (2017) Selenium, arsenic and molybdenum and bio-radiation in the Ediacaran-Cambrian interval. Pre Res 292:378-385
Van Mooy BAS, Rocap G, Fredricks HF, Evans CT, Devol AH (2006) Sulfolipids dramatically decrease phosphorus demand by picocyanobacteria inoligotrophic marine environments. Proc Natl Sci USA 103(23):8607-8612

Van Mooy BAS, Fredricks HF, Pedler BE, Dyhrman ST, Karl DM, Koblížek M, Lomas MW, Mincer TJ, Moore LR, Moutin T, Rappé MS, Webb EA (2009) Phytoplankton in the ocean use non-phosphorus lipids in response to phosphorus scarcity. Nature 458:69-72

Villalobos M, Escobar-Quiroz IN, Camacho CS (2014) The influence of particle size and structure on the sorption and oxidation behavior of birnessite: I. Adsorption of As(V) and oxidation of As(III). Geochem Cosmo Acta 125:564-581

Viollier R, Inglett PW, Hunter K, Roychoudhury AN, Van Cappellen P (2000) The ferrozine method revisited: Fe(II)/ $\mathrm{Fe}$ (III) determination in natural waters. Appl Geochem 15(6):785-790

Wheat GC, Feely RA, Mottl MJ (1996) Phosphate removal by oceanic hydrothermal processes: an update of the phosphorus budget in the oceans. Geochim Cosmochim Acta 60(19):3593-3608

Wilkin RT, Wallschläger D, Ford RG (2003) Speciation of arsenic in sulfidic waters. Geochem Trans. https://doi.org/ 10.1186/1467-4866-4-1

$\mathrm{Xu} \mathrm{Y,} \mathrm{Nussinov} \mathrm{R} \mathrm{(2012)} \mathrm{Structural} \mathrm{and} \mathrm{functional} \mathrm{conse-}$ quences of phosphate-arsenate substitutions in selected nucleotides: DNA, RNA, and ATP. J Phys Chem B 116(16):4801-4811

Zhu Y-G, Yoshinaga M, Zhao F-J, Rosen BP (2014) Earth abides arsenic biotransformations. Annu Rev Earth Planet Sci 42:443-467

Zhu YG, Xue XM, Kappler A, Rosen BP, Meharg AA (2017) Linking genes to microbial biogeochemical cycling: lessons from arsenic. Environ Sci Technol 51:7326-7339 